\title{
Immunological Profiling of COVID-19 Patients with Pulmonary Sequelae
}

\author{
Jianghua Wu, a,b Lu Tang, ${ }^{\text {a,b }}$ Yanling Ma, ${ }^{c}$ Yu Li,c (DDongmei Zhang, ${ }^{c}$ Qian Li, ${ }^{\text {a,b }}$ Heng Mei, ${ }^{a, b}$ Yu Hu ${ }^{a, b}$ \\ alnstitute of Hematology, Union Hospital, Tongji Medical College, Huazhong University of Science and Technology, Wuhan, China \\ bHubei Clinical Medical Center of Cell Therapy for Neoplastic Disease, Wuhan, China \\ 'Department of Respiratory and Critical Care Medicine, Union Hospital, Tongji Medical College, Huazhong University of Science and Technology, Wuhan, China
}

Jianghua Wu, Lu Tang, Yanling Ma, and Yu Li contributed equally to this article. Author order was determined by contributions to investigation.

ABSTRACT Cellular immunity may be involved in organ damage and rehabilitation in patients with coronavirus disease 2019 (COVID-19). We aimed to delineate immunological features of COVID-19 patients with pulmonary sequelae (PS) 1 year after discharge. Fifty COVID-19 survivors were recruited and classified according to radiological characteristics, including 24 patients with PS and 26 patients without PS. Phenotypic and functional characteristics of immune cells were evaluated by multiparametric flow cytometry. Patients with PS had an increased proportion of natural killer (NK) cells and a lower percentage of B cells than patients without PS. Phenotypic and functional features of $\mathrm{T}$ cells in patients with PS were predominated by the accumulation of $\mathrm{CD} 4$-positive $\left(\mathrm{CD}^{+}\right) \mathrm{T}$ cells secreting interleukin $17 \mathrm{~A}$ (IL-17A), short-lived effector-like CD8 ${ }^{+}$T cells (CD27-negative [CD27-] $\mathrm{CD}^{-} \mathrm{L}^{-}$), and senescent $T$ cells with excessive secretion of granzyme B/perforin/interferon gamma (IFN- $\gamma$ ). NK cells were characterized by the excessive secretion of granzyme $B$ and perforin and the downregulation of NKP30 and NKP46; highly activated NKT and $\gamma \delta$ T cells exhibited NKP30 and TIM-3 upregulation and NKB1 downregulation in patients with PS. However, immunosuppressive cells were comparable between the two groups. The interrelationship of immune cells in COVID-19 was intrinsically identified, whereby $T$ cells secreting IL-2, IL-4, and IL-17A were enriched among $\mathrm{CD}_{28}{ }^{+}$and $\mathrm{CD}_{57}{ }^{-}$cells and cells secreting perforin/granzyme B/IFN- $\gamma /$ tumor necrosis factor alpha (TNF- $\alpha$ )-expressed markers of terminal differentiation. $\mathrm{CD}_{57}{ }^{+} \mathrm{NK}$ cells, CD4 ${ }^{+}$Perforin ${ }^{+} \mathrm{T}$ cells, and $\mathrm{CD}^{+}{ }^{+} \mathrm{CD} 27^{+} \mathrm{CD}^{+} 2 \mathrm{~L}^{+} \mathrm{T}$ cells were identified as the independent predictors for residual lesions. Overall, our findings unveil the profound imbalance of immune landscape that may correlate with organ damage and rehabilitation in COVID-19.

IMPORTANCE A considerable proportion of COVID-19 survivors have residual lung lesions such as ground-glass opacity and fiber streak shadow. To determine the relationship between host immunity and residual lung lesions, we performed an extensive analysis of immune responses in convalescent patients with COVID-19 1 year after discharge. We found significant differences in immunological characteristics between patients with pulmonary sequelae and patients without pulmonary sequelae 1 year after discharge. Our study highlights the profound imbalance of immune landscape in the COVID-19 patients with pulmonary sequelae, characterized by the robust activation of cytotoxic T cells, NK cells, and $\gamma \delta$ T cells, as well as the deficiencies of immunosuppressive cells. Importantly, CD57 ${ }^{+} \mathrm{NK}$ cells, $\mathrm{CD}^{+}{ }^{+}$Perforin ${ }^{+} \mathrm{T}$ cells, and $\mathrm{CD} 8{ }^{+} \mathrm{CD}_{2} 7^{+} \mathrm{CD}_{2} \mathrm{~L}^{+} \mathrm{T}$ cells were identified as the independent predictors for residual lesions.
Citation Wu J, Tang L, Ma Y, Li Y, Zhang D, Li Q Mei H, Hu Y. 2021. Immunological profiling of COVID-19 patients with pulmonary sequelae. mBio 12:e01599-21. https://doi.org/10.1128/ mBio.01599-21.

Invited Editor Jose Luis Villarreal-Camacho Universidad Libre

Editor Avery August, Cornell University

Copyright $\odot 2021$ Wu et al. This is an openaccess article distributed under the terms of the Creative Commons Attribution 4.0 International license.

Address correspondence to Heng Mei, hmei@hust.edu.cn, or Yu Hu,

dr_huyu@126.com

Received 2 June 2021

Accepted 28 July 2021

Published 7 September 2021

KEYWORDS COVID-19, cellular immunity, pulmonary sequelae 
s of early May 2021, more than 150 million people have developed coronavirus disease (COVID-19), a pandemic that has killed approximately 3 million people. Caused by acute respiratory syndrome coronavirus 2 (SARS-CoV-2), COVID-19 exhibits a highly variable clinical course, ranging from a high proportion of asymptomatic and mild infections to severe and fatal disease (1). With the help of interventions and immediate medical support, most patients have recovered. Nevertheless, a considerable proportion of survivors have unresolved health issues, such as pulmonary fibrosis and gas diffusion impairment (2). Thus, understanding the clinical and immunological features of convalescent individuals is critically important to elucidate the immunopathogenesis of COVID-19 and facilitate the development of effective immune interventions.

Early infection with SARS-CoV-2 can induce efficient innate immunity, followed by an adaptive immune response to control the virus (3). Such synchronized interaction between innate and adaptive immunity exquisitely mediates both viral control and host toxicity in COVID-19. Although activated immune cells orchestrate a protective function against SARS-CoV-2, they also participate in tissue damage if overactivated by inflammatory stimuli (4). Numerous studies have investigated humoral and cellular immune responses in patients who have recovered from COVID-19 (5-7). For example, peripheral blood SARS-CoV-2-specific T cells are detectable in convalescent patients, especially SARS-CoV-2-specific CD8-positive $\left(C D 8^{+}\right)$and $C D 4^{+} \mathrm{T}$ cells, which correlated not only with serum-neutralizing activities but also with disease severity (7-11). One study detected both virus-specific memory $B$ and $T$ cells in individuals who have recovered from mildly symptomatic COVID-19, showing that these cells not only persist but, in some cases, increased numerically over 3 months after symptom onset (5). However, it remains unclear how cellular immunity mediates long-term protective and pathogenic inflammation in COVID-19.

Similar to influenza virus infection (12), SARS-CoV-2-mediated lung damage entails the interplay among aberrantly activated monocytes/macrophages producing interleukin 1 beta (IL-1 $\beta)$, inflammation-induced impairment of alveolar epithelial regeneration, and expansion of $\mathrm{CTHRC}^{+}$pathological fibroblasts that promoted fibrosis and may impair regeneration (13). Zhao et al. identified clonally expanded tissue-resident Th17 cells in the lungs of patients even after SARS-CoV-2 clearance, which may interact with profibrotic macrophages and cytotoxic $\mathrm{CD} 8^{+} \mathrm{T}$ cells, leading to the formation of pulmonary fibrosis (4). Although lung lesions in COVID-19 patients could be completely absorbed during follow-up with no sequelae, residual ground-glass opacification, interstitial thickening, or fibrotic-like changes were observed in most patients who survived severe COVID-19 $(2,14,15)$. Immunologic determinants underlying pulmonary sequelae (PS) are not fully understood in COVID-19. To determine the immunopathogenesis of PS, we recruited 24 COVID-19 survivors with PS and 26 patients without PS and performed comprehensive assessments of immunological profiling. Our study highlights the profound imbalance of immune landscape in COVID-19 patients with PS, as characterized by robust activation of cytotoxic T cells, natural killer (NK) cells, and $\gamma \delta$ T cells, as well as deficiencies in immunosuppressive cells.

\section{RESULTS}

Clinical characteristics of convalescent patients with COVID-19. A total of 50 convalescent patients with COVID-19 were included and categorized as 24 patients with PS (PPSs) and 26 patients without PS (NPSs) based on radiological characteristics. As shown in Table 1, the mean age of all patients was 53.96 years, with a significantly older age for PPSs than NPSs (59.63 versus 48.73; $P<0.0003$ ). The most common comorbidities among the patients were $20.00 \%$ with hypertension, $14.00 \%$ with diabetes mellitus, and $10.00 \%$ with cardiopathy. Nasopharyngeal swab SARS-CoV-2 RNA detection was negative in all patients 1 year after discharge (Table 1). SARS-CoV-2 IgM (2 patients; $8.33 \%$ ) and IgG levels $(22 ; 91.67 \%)$ in PPSs were positive, while SARS-CoV-2 $\lg M(2 ; 7.69 \%)$ and IgG levels $(23 ; 88.46 \%)$ in NPSs were positive (Table 1$)$. The predominant patterns of PS were ground-glass opacity $(24 ; 100.00 \%)$, fiber streak shadow $(21$, 
TABLE 1 Demographics and clinical characteristics of COVID-19 patients ${ }^{a}$

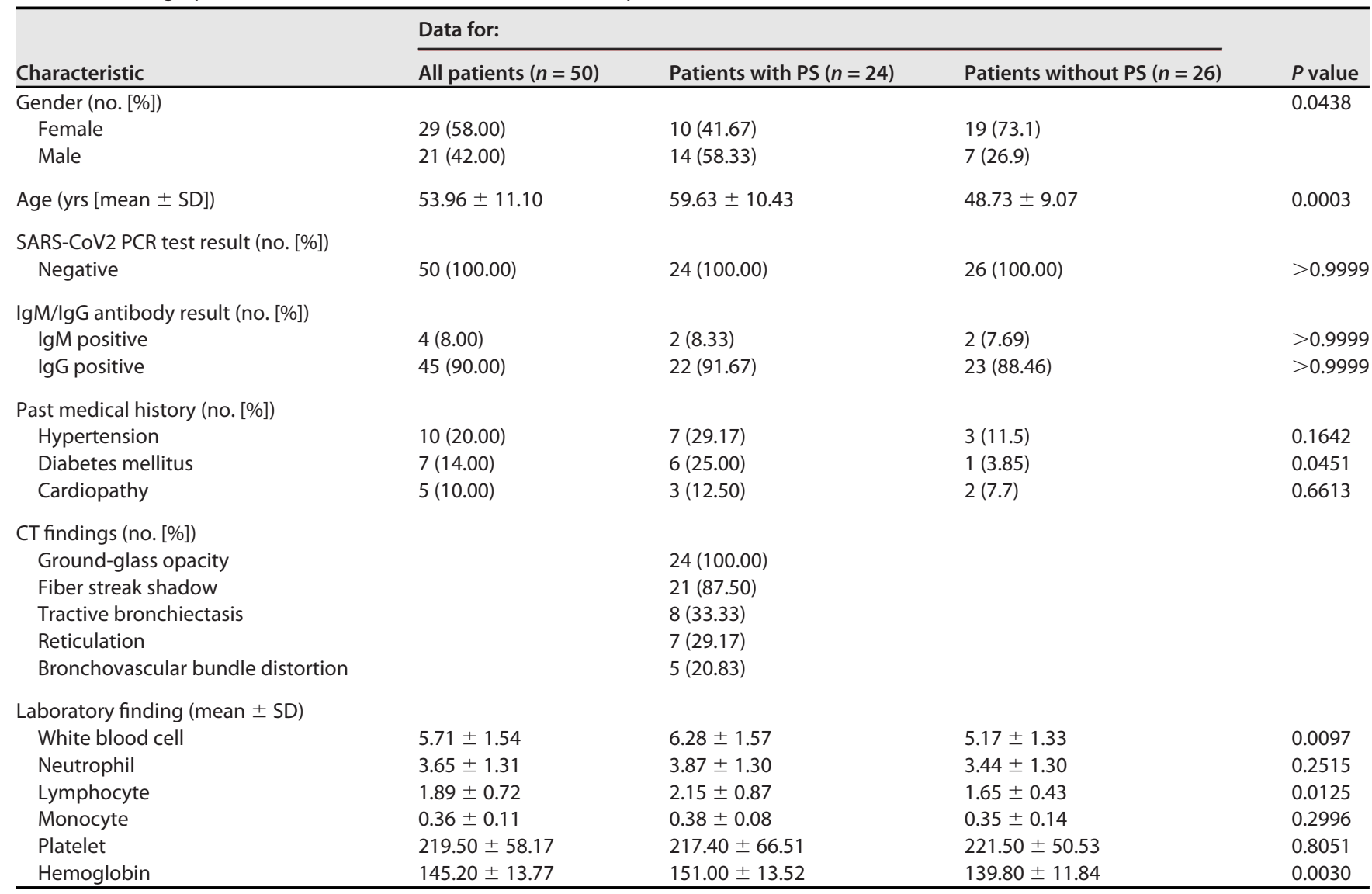

${ }^{a}$ Data are presented as mean \pm standard deviation (SD) and no. (\%) of patients with available data. $P$ values comparing patients with PS and patients without PS are from Fisher's exact test or unpaired 2-sided Student's $t$ test. COVID-19, coronavirus disease 2019; SARS-CoV-2, severe acute respiratory syndrome coronavirus 2; CT, computed tomography; PS, pulmonary sequelae.

87.50\%), and tractive bronchiectasis (8, 33.33\%) in PPSs (Table 1). Representative chest computed tomography (CT) scans longitudinally exhibited the change of lung lesions (Fig. 1A). Although the lung lesions gradually resolved in all patients, ground-glass opacity, (GGO), fiber streak shadow, tractive bronchiectasis, reticulation, and bronchovascular bundle distortion could be observed in the representative patients (Fig. 1A to C). Importantly, there was a statistically significant increment in hemoglobin in PPSs in comparison to NPSs (Table 1), suggesting that residual pulmonary lesions may influence diffusion capacity and induce a compensatory increase in hemoglobin in those with PS.

NK cells and short-lived effector-like CD8 ${ }^{+}$T cells accumulate in PPSs. Immunologic disturbance induced by SARS-CoV-2 infection is characterized by lymphopenia in those with acute COVID-19 (16). Strikingly, white blood cell and lymphocyte counts were higher in PPSs than NPSs 1 year after discharge, whereas no significant differences in neutrophil, monocyte, and platelet counts were found between the two groups (Table 1). We next analyzed the presence of lymphocyte subsets to obtain an overview of the general distribution in the peripheral blood. The NK cell percentage was significantly higher in PPSs than in NPSs, but there were no significant differences in $\mathrm{CD}^{+} \mathrm{T}$, $\mathrm{CD}^{+} \mathrm{T}, \mathrm{CD}^{+} \mathrm{T}, \mathrm{NKT}$, and $\gamma \delta \mathrm{T}$ cell percentages (Fig. 2A). A decreased proportion of $\mathrm{B}$ cells was detected in PSSs, though the memory $B$ cell frequency was not significantly different (Fig. 2A and B).

We next performed immunophenotypic analyses of circulating $\mathrm{CD}^{+}$and $\mathrm{CD}^{+}{ }^{+} \mathrm{T}$ cells to identify their state of differentiation, exhaustion, and senescence. CD27 and CD62L were used to distinguish maturation and memory subsets in $\mathrm{CD}^{+}$and $\mathrm{CD} 8^{+} \mathrm{T}$ 


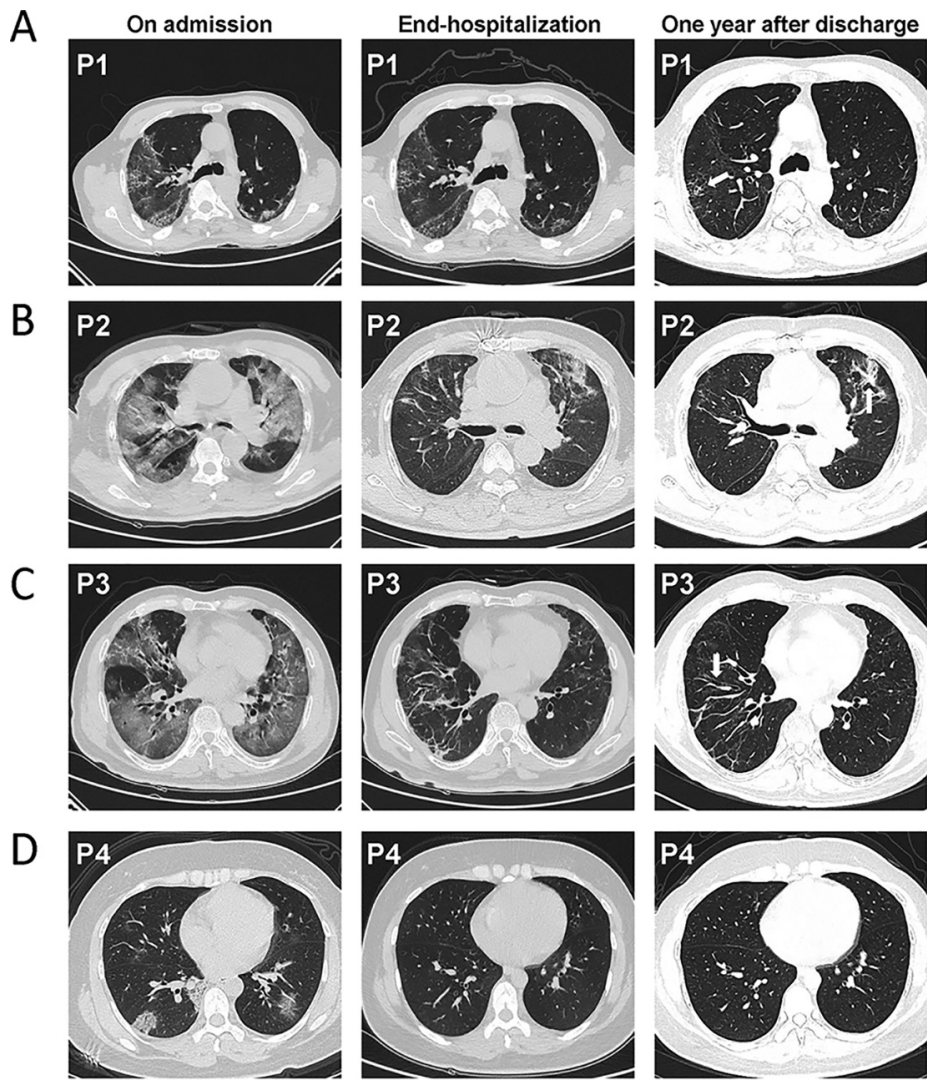

FIG 1 Chest computed tomography scan of four patients across three time periods, including on admission, end of hospitalization, and 1 year after discharge. (A to D) Chest CT of three time periods showed the change of lung lesions from 3 patients with pulmonary sequelae (P1, P2, and P3) and 1 patient without pulmonary sequelae (P4). (A) CT image of a 61-year-old man (P1) showing groundglass opacity (GGO), fiber streak shadow, and reticulation 1 year after discharge. (B) CT image of a 77year-old man (P2) showing GGO, fiber streak shadow, and bronchovascular bundle distortion 1 year after discharge. (C) CT image of a 58-year-old man (P3) showing GGO, fiber streak shadow, and tractive bronchiectasis 1 year after discharge. (D) CT image of a 36-year-old woman (P4) showing complete resolution of lung lesions 1 year after discharge.

cells. We found no significant differences in $\mathrm{CD}^{+}{ }^{+} \mathrm{T}$ cell populations based on $\mathrm{CD} 27$ and CD62L expression between PPSs and NPSs (Fig. 2C). CD27-negative (CD27-) $\mathrm{CD} 2 \mathrm{~L}^{-} \mathrm{T}$ cells represent short-lived effector-like $\mathrm{T}$ cells characterized by the enrichment for antigen-experienced and senescent $T$ cells, while $C D 27^{+} \mathrm{CD}_{2} \mathrm{~L}^{+} \mathrm{T}$ cells consist of naive $T$ cells and central memory $T$ cells (17). Importantly, there was a statistically significant increase in the $\mathrm{CD}^{+} \mathrm{CD}^{2} 7^{-} \mathrm{CD} 2 \mathrm{~L}^{-} \mathrm{T}$ cells percentage in PPSs, yet the $\mathrm{CD}^{+} \mathrm{CD}^{2} 7^{+} \mathrm{CD}_{22 \mathrm{~L}^{+}} \mathrm{T}$ cell frequency was significantly reduced (Fig. 2C). $\mathrm{CD} 4{ }^{+} \mathrm{CD} 57^{+}$ T cells percentage tended to be higher in PPSs than in NPSs, though there was no statistical difference (Fig. 2D). A higher percentage of $\mathrm{CD}^{+} \mathrm{CD} 57^{+} \mathrm{T}$ cells was observed in PPSs (Fig. 2D). Moreover, increases of both $\mathrm{CD}^{+} \mathrm{T}$ and $\mathrm{CD} 8^{+} \mathrm{T}$ cells expressing KLRG-1 and TIM-3 were detected in PPSs, with no changes in the frequencies of CD28and PD-1-expressing T cells between PPSs and NPSs (Fig. 2D).

Circulating NK cells and innate-like lymphocytes exhibit distinct phenotypes between PPSs and NPSs. NK, NKT, and $\gamma \delta$ T cells, large granular lymphocytes with the ability to lyse virally infected cells, are important components of antiviral immunity (18-20). Having established that PPSs displayed an increase in the NK cells percentage, we further analyzed the NK cell phenotype. Importantly, there was a statistically significant increment in NK cells expressing CD57, whereas the frequencies of NKP30- and NKP46-expressing NK cells were significantly reduced in PPSs (Fig. 3A). No changes in the frequencies of CD27-, KLRG1-, PD-1-, TIM-3-, NKB1-, NKG2A-, and NKG2D-expressing NK cells were noted between the two groups (Fig. 3A). Focusing on NKT cells, we 
A
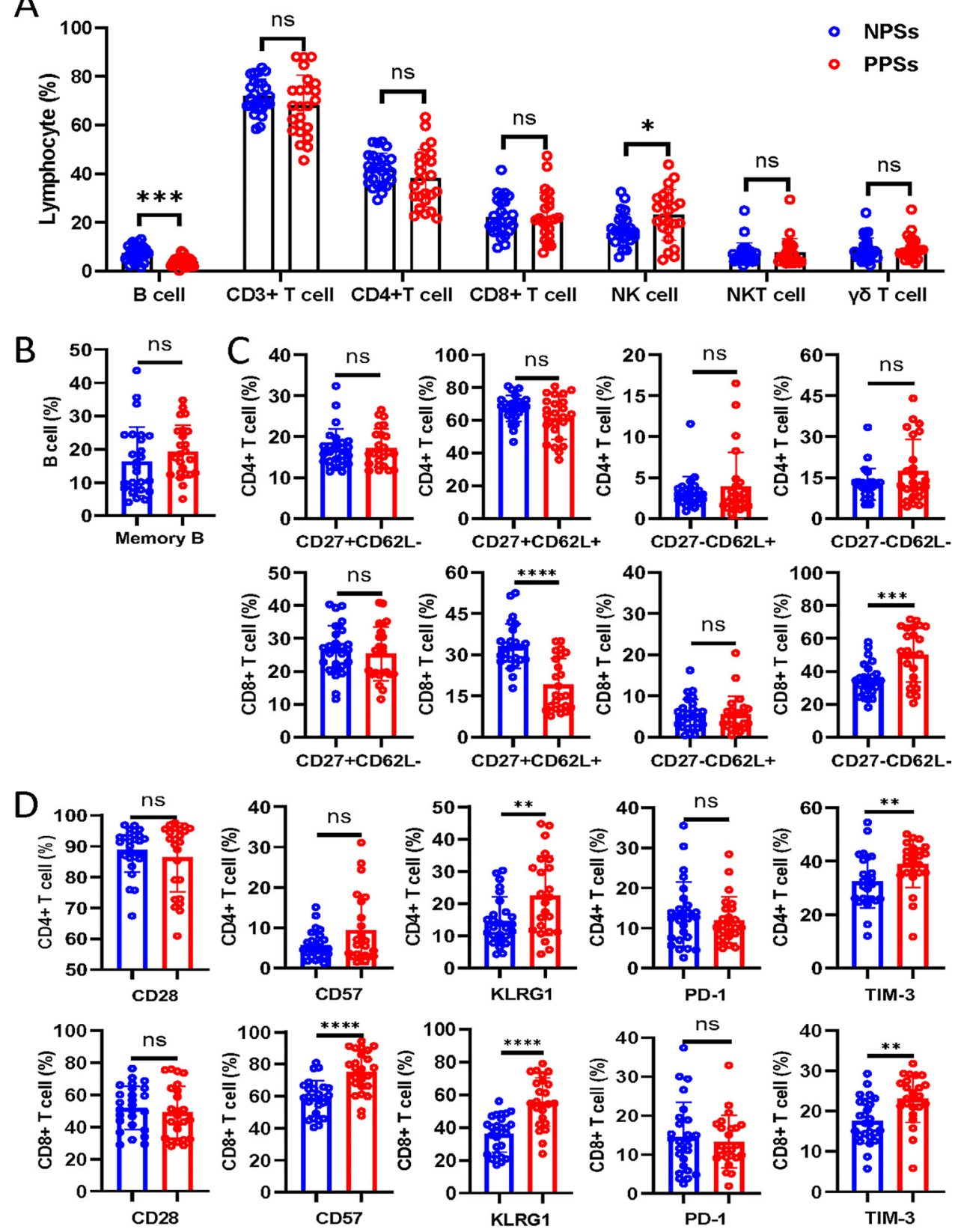

FIG 2 Lymphocyte composition and immunophenotypic characterization of B and T cells in convalescent COVID-19 patients. Circulating lymphocytes from COVID-19 patients with pulmonary sequelae (PPSs; $n=24)$ and patients without pulmonary sequelae (NPSs; $n=26$ ) were analyzed by multiparameter flow cytometry. (A) Relative proportions of $\mathrm{CD}^{+} \mathrm{T}, \mathrm{CD}^{+} \mathrm{T}, \mathrm{CD} 8^{+} \mathrm{T}, \mathrm{NK}, \mathrm{NKT}, \gamma \delta \mathrm{T}$, and $\mathrm{B}$ cells between the two groups. (B) Relative proportions of memory and naive $B$ cells between the two groups. (C) Relative proportions of CD4/

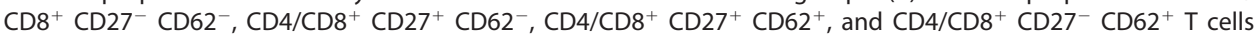
between the two groups. (D) Relative proportions of $\mathrm{CD} 4 / \mathrm{CD} 8^{+} \mathrm{CD} 28^{+}, \mathrm{CD} 4 / \mathrm{CD} 8^{+} \mathrm{CD} 57^{+}, \mathrm{CD} / \mathrm{CD} 8^{+} \mathrm{KLRG}^{+}$, $\mathrm{CD} 4 / \mathrm{CD}^{+} \mathrm{PD}^{-1}{ }^{+} \mathrm{T}$ cells, and $\mathrm{CD} 4 / \mathrm{CD}^{+} \mathrm{TIM}^{-3^{+}} \mathrm{T}$ cells between the two groups. Data are mean $\pm \mathrm{SD}$. The Mann-Whitney $U$ test or unpaired two-tailed Student's $t$ tests were used to compare the two groups. * $P<0.05 ;{ }^{* *}, P<0.01 ;{ }^{* * *}, P<0.001 ;{ }^{* * *}, P<0.0001$.

observed an increase in the fraction of those expressing TIM-3 and NKP30, but the fraction of NKB1 ${ }^{+}$NKT cells was markedly decreased in PPSs (Fig. 3B), suggesting that NKT cells exhibit an activated or exhausted state. However, there were no significant differences in the frequencies of CD27-, CD57-, KLRG1-, PD-1-, NKG2A-, NKG2D- and NKP46expressing NKT cells between the two groups (Fig. 3B). Moreover, $\gamma \delta$ T cells from PPSs overexpressed CD57, KLRG1, TIM-3, and NKP30 (Fig. 3C), which is compatible with a 
A
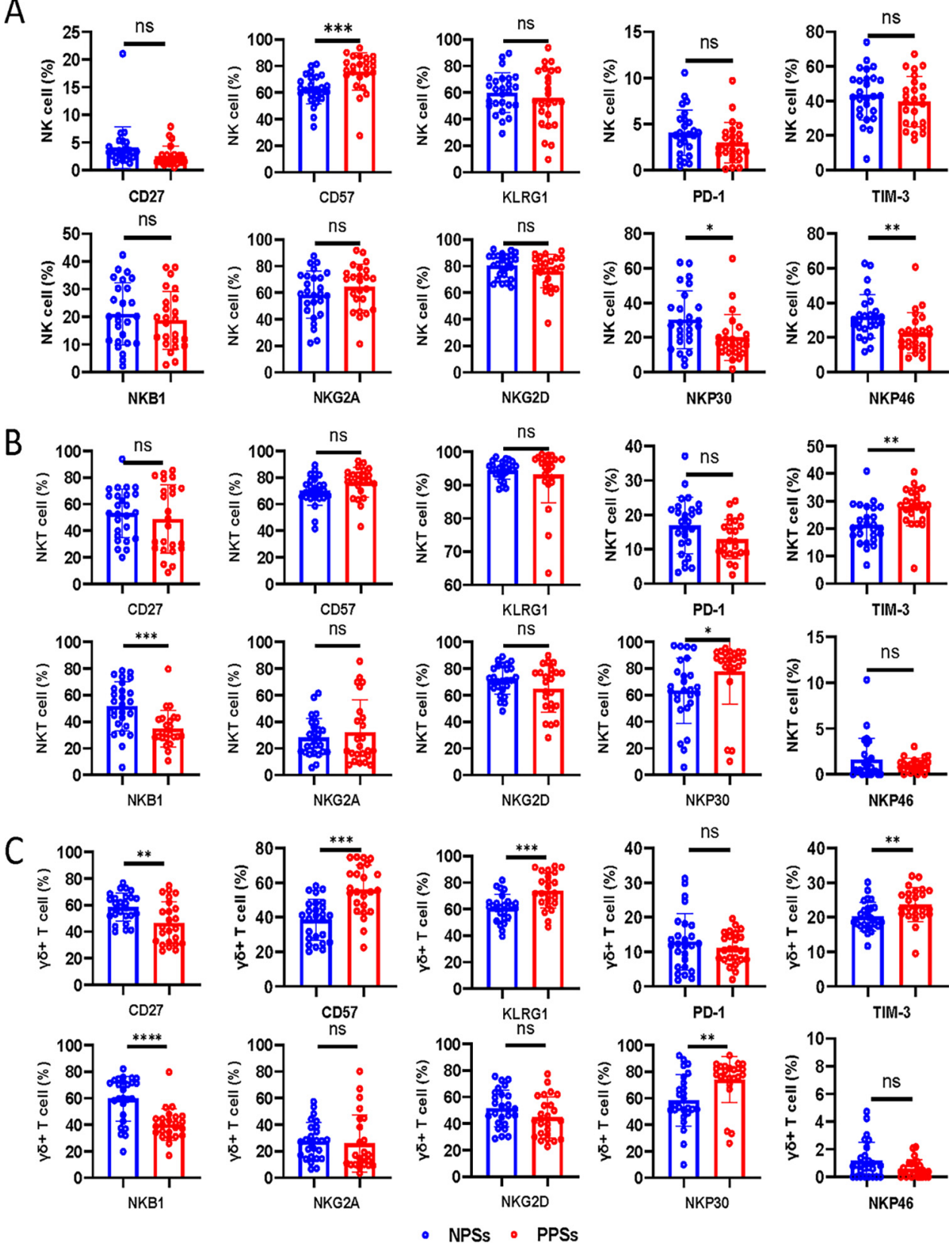

FIG 3 Phenotypical features of NK, NKT, and $\gamma \delta$ T cells in convalescent COVID-19 patients. Circulating NK, NKT, and $\gamma \delta$ T cells from COVID-19 patients with pulmonary sequelae (PPSs; $n=24$ ) and patients without pulmonary sequelae (NPSs; $n=26$ ) were analyzed by multiparameter flow cytometry. (A) Relative proportions of CD27, CD57, KLRG1, PD-1, TIM-3, NKB1, NKG2A, NKG2D, NKP30, and NKP46 expression on NK cells between the two groups. (B) Relative proportions of CD27, CD57, KLRG1, PD-1, TIM-3, NKB1, NKG2A, NKG2D, NKP30, and NKP46 expression on NKT cells between the two groups. (C) Relative proportions of CD27, CD57, KLRG1, PD-1, TIM-3, NKB1, NKG2A, NKG2D, NKP30, and NKP46 expression on $\gamma \delta$ T cells between the two groups. Data are mean \pm SD. Mann-Whitney $U$ test or unpaired two-tailed Student's $t$ tests were used to compare the two groups. *, $P<0.05 ;{ }^{* *}, P<0.01 ;{ }^{* * *}, P<0.001 ;{ }^{* * *}, P<0.0001$.

senescent, hyperactivated exhaustion profile. Downregulation of the inhibitory receptor NKB1 and CD27 in $\gamma \delta$ T cells was found in PPSs, but PD-1, NKG2A, and NKP46 expressions were unaffected (Fig. 3C).

Coexistence of senescence and exhaustion phenotypic signatures in cytokinesecreting cells in PPSs. We next assessed cytokine production in $\mathrm{CD}^{+} \mathrm{T}$ cells after stimulation with PMA and ionomycin and observed that, in comparison to NPSs, CD4 ${ }^{+}$T cells from PPSs overexpressed IL-17A and interferon gamma (IFN- $\gamma$ ) but not IL-2, IL-4, or tumor 
A

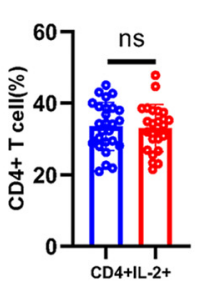

B

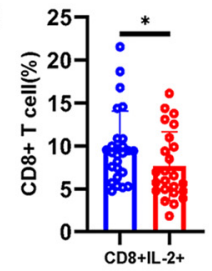

C
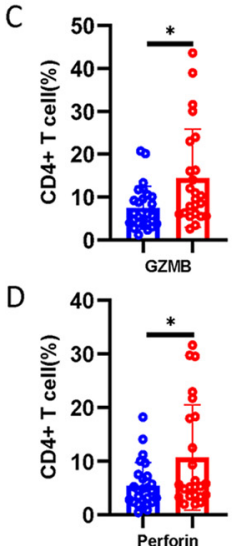
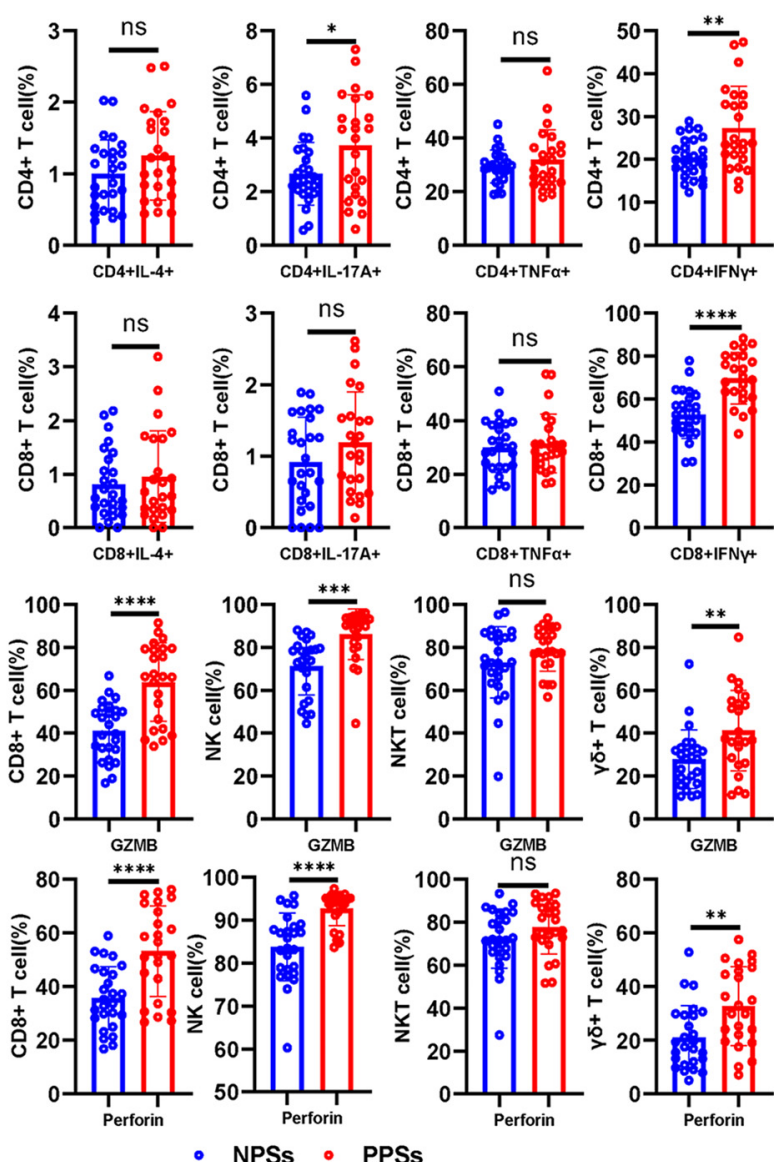

FIG 4 Functional characterization of $\mathrm{CD}^{+} \mathrm{T}, \mathrm{CD}^{+} \mathrm{T}$, NK, NKT, and $\gamma \delta \mathrm{T}$ cells. Circulating $\mathrm{CD}^{+} \mathrm{T}^{+}$ $\mathrm{CD}^{+} \mathrm{T}, \mathrm{NK}, \mathrm{NKT}$, and $\gamma \delta$ T cells from COVID-19 patients with pulmonary sequelae (PPSs; $\left.n=24\right)$ and patients without pulmonary sequelae (NPSs; $n=26$ ) were analyzed by multiparameter flow cytometry. (A) Relative proportions of $\mathrm{CD} 4^{+} \mathrm{IL}-2^{+}, \mathrm{CD} 4^{+} \mathrm{IL}-4^{+}, \mathrm{CD} 4^{+} \mathrm{IL}-17 \mathrm{~A}^{+}, \mathrm{CD} 4^{+} \mathrm{IFN}-\gamma^{+}$, and $\mathrm{CD} 4^{+}$ TNF- $\alpha^{+}$T cells between the two groups. (B) Relative proportions of CD8 ${ }^{+} \mathrm{IL}-2^{+}, \mathrm{CD} 8^{+} \mathrm{IL}-4^{+}, \mathrm{CD}^{+} \mathrm{IL}^{-}$ $17 \mathrm{~A}^{+}, \mathrm{CD}^{+} \mathrm{IFN}-\gamma^{+}$, and $\mathrm{CD} 8^{+} \mathrm{TNF}-\alpha^{+} \mathrm{T}$ cells between the two groups. (C) Relative proportions of perforin in circulating $\mathrm{CD}^{+} \mathrm{T}, \mathrm{CD}^{+} \mathrm{T}, \mathrm{NK}, \mathrm{NKT}$, and $\gamma \delta$ T cells between the two groups. (D) Relative proportions of GZMB in circulating $\mathrm{CD}^{+} \mathrm{T}, \mathrm{CD}^{+} \mathrm{T}, \mathrm{NK}, \mathrm{NKT}$, and $\gamma \delta \mathrm{T}$ cells between the two groups. Data are mean $\pm S D$. The Mann-Whitney $U$ test or unpaired two-tailed Student's $t$ tests were used to compare the two groups. ${ }^{*}, P<0.05 ;{ }^{* *}, P<0.01 ;{ }^{* * *}, P<0.001 ;{ }^{* * *}, P<0.0001$.

necrosis factor alpha (TNF- $\alpha$ ) (Fig. 4A). The frequency of IFN- $\gamma$ expression was higher among $\mathrm{CD}^{+}{ }^{+} \mathrm{T}$ cells in PPSs than NPSs, with no significant differences in IL-4, IL-17A, and TNF- $\alpha$ production in CD8 ${ }^{+}$T cells between the two groups (Fig. 4B). Nonetheless, $\mathrm{CD}^{+} \mathrm{T}$ cells from PPSs showed downregulated IL-2 expression compared with NPSs (Fig. 4B). We next investigated the degranulation capacity and cytotoxic molecule expression in $\mathrm{CD}^{+}$ $\mathrm{T}, \mathrm{CD} 8^{+} \mathrm{T}, \mathrm{NK}, \mathrm{NKT}$, and $\gamma \delta \mathrm{T}$ cells. Based on functional characterization, $\mathrm{CD} 4^{+} \mathrm{T}, \mathrm{CD} 8^{+} \mathrm{T}$, NK, and $\gamma \delta$ T cells exhibited upregulation of granzyme B (GZMB) and perforin in PPSs compared with NPSs (Fig. $4 \mathrm{C}$ and D). However, no significant differences in GZMB and perforin expression in NKT cells were observed (Fig. 4C and D).

We next used a clustering and visualization strategy to investigate the coexpression of CD27, CD28, PD-1, and CD57, together with cytokines (IL-2, IL-4, IL-17A, TNF- $\alpha$, and IFN- $\gamma$ ) and cytotoxic molecules (GZMB and perforin) (Fig. $5 \mathrm{~A}$ and $\mathrm{B}$ and Fig. $\mathrm{S} 1 \mathrm{H}$ to $\mathrm{I}$ in the supplemental material). The advantage of this analysis lies in its integration of surface and functional markers at a single-cell level, providing an improved understanding of their high-dimensional relationship. CD4 ${ }^{+} \mathrm{IL}-2^{+}, \mathrm{CD} 4^{+} \mathrm{IL}-4^{+}$, and $\mathrm{CD} 4^{+} \mathrm{IL}-17 \mathrm{~A}^{+} \mathrm{T}$ cells hardly expressed CD57 (Fig. 5A). Phenotypic characterization further demonstrated that $\mathrm{CD}^{+}{ }^{+} \mathrm{T}$ cells expressing IL-2, IL-4, and IL-17A were prominent among the 


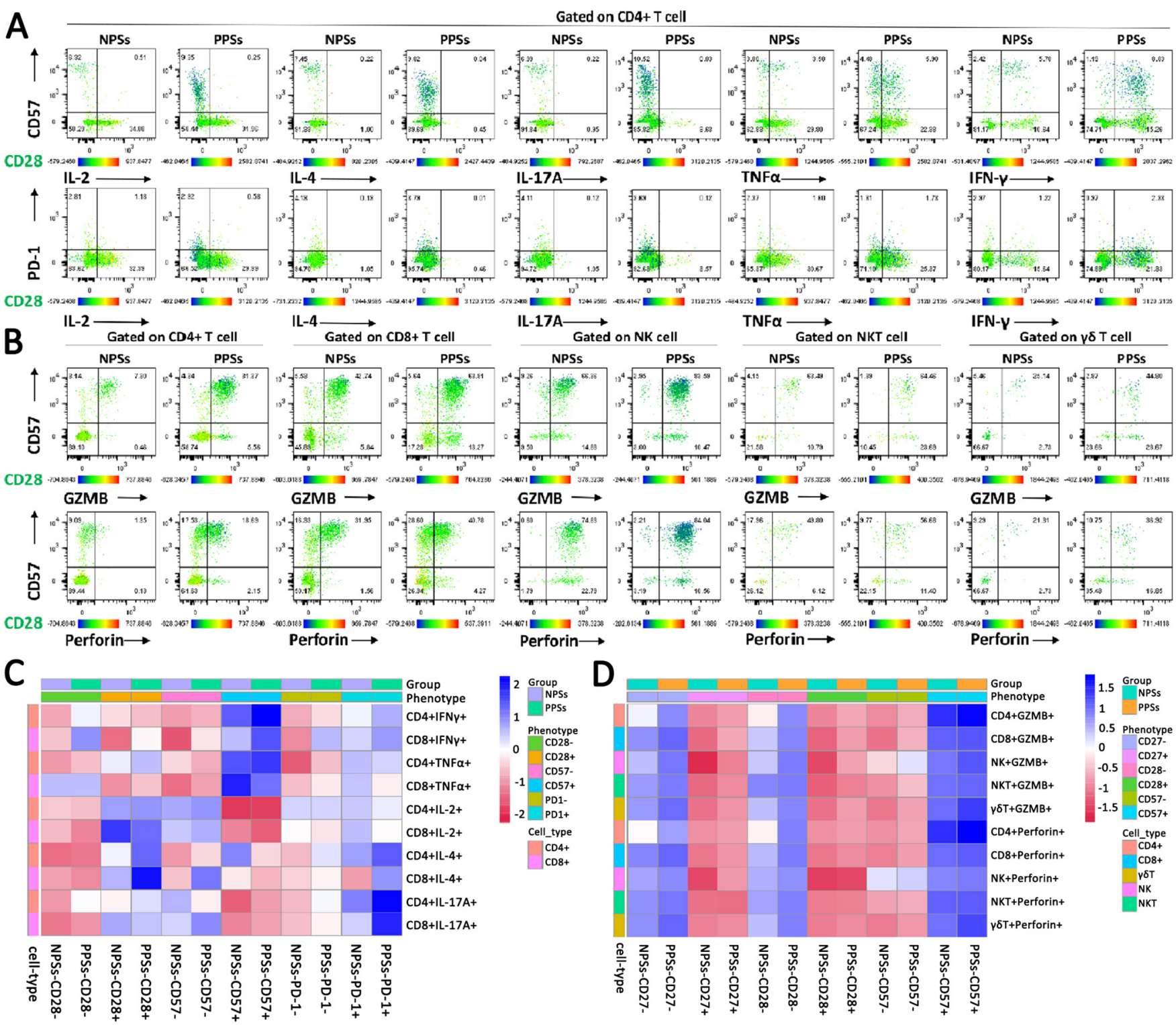

FIG 5 Senescence and exhaustion phenotypes coexist in cytokine-secreting CD4 ${ }^{+} \mathrm{T}_{1} \mathrm{CD} 8^{+} \mathrm{T}$, NK, NKT, and $\gamma \delta$ T cells. The coexpression of CD27, CD28, and

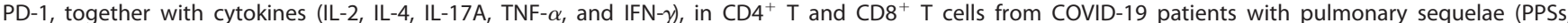
$n=24$ ) and patients without pulmonary sequelae (NPSs; $n=26$ ) was analyzed by multiparameter flow cytometry. (A) Bidimensional map obtained from flow cytometric data displaying the coexpression of CD27, CD28, and PD-1, together with cytokines (IL-2, IL-4, IL-17A, TNF- $\alpha$, and IFN- $\gamma$ ), in CD4 ${ }^{+}$T cell. Figure $\mathrm{S} 1 \mathrm{H}$ in the supplemental material displays the coexpression of CD27, CD28, and PD-1, together with cytokines (IL-2, IL-4, IL-17A, TNF- $\alpha$, and IFN- $\gamma$ ), in

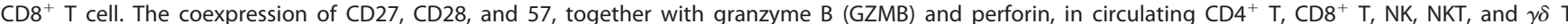
cells from COVID-19 PPSs $(n=24)$ and NPSs $(n=26)$ was analyzed by multiparameter flow cytometry. (B) Bidimensional map obtained from flow cytometric data displaying the coexpression of CD28 and CD57, together with GZMB and perforin, in CD4 ${ }^{+} \mathrm{T}_{1} \mathrm{CD}^{+} \mathrm{T}^{+} \mathrm{NK}, \mathrm{NKT}$, and $\gamma \delta \mathrm{T}$ cells. Figure S1 displays the coexpression of CD27 and CD57, together with GZMB and perforin, in CD4 ${ }^{+} \mathrm{T}_{\text {, CD8 }}^{+} \mathrm{T}_{\text {, NK, NKT, and } \gamma \delta} \mathrm{T}$ cells. (C) Heatmap represents the percentage of cells in $\mathrm{CD}_{2} 7^{+}, \mathrm{CD} 27^{-}, \mathrm{CD} 28^{+}, \mathrm{CD} 28^{-}, \mathrm{PD}-1^{+}$, and PD-1- clusters that express IL-2, IL-4, IL-17A, TNF- $\alpha$, and IFN- $\gamma$ in $\mathrm{CD} 4{ }^{+} \mathrm{T}$ and $\mathrm{CD} 8^{+} \mathrm{T}$ cells

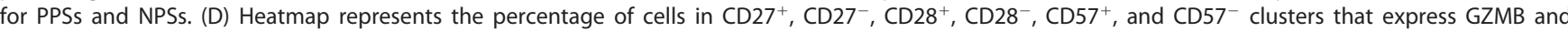
perforin in $\mathrm{CD}^{+} \mathrm{T}, \mathrm{CD} 8^{+} \mathrm{T}, \mathrm{NK}, \mathrm{NKT}$, and $\gamma \delta \mathrm{T}$ cells for PSSs and NPSs.

$\mathrm{CD}^{2} 8^{+} \mathrm{T}$ cells (Fig. 5A). According to a representative scatterplot, IFN- $\gamma$ could be secreted by $\mathrm{CD}^{+}{ }^{+} \mathrm{CD} 57^{+} \mathrm{T}$ cells and $\mathrm{CD} 4^{+} \mathrm{CD} 57^{-} \mathrm{T}$ cells; furthermore, $\mathrm{CD}^{+}{ }^{+} \mathrm{CD} 57^{+}$ IFN- $\gamma^{+}$T cells were enriched among CD4 ${ }^{+}$CD28- ${ }^{-}$T cells (Fig. 5A). As observed in $\mathrm{CD}^{+}$ T cells, the coexpression of IL-2, IL-4, and IL-17A, together with CD28 and CD57, could be similarly observed in $\mathrm{CD}^{+} \mathrm{T}$ cells (Fig. S1H). Next, we investigated whether PD-1 expression correlates with cytokine production in the $T$ cell population. We found that IL-2, IL-4, IL-17A, TNF- $\alpha$, and IFN- $\gamma$ expression was mainly distributed in PD-1 ${ }^{-}$T cells (Fig. $5 \mathrm{~A}$ and Fig. $\mathrm{S} 1 \mathrm{H}$ ). We summarized these data in a heatmap and exhibited the 
distributions of IL-2, IL-4, IL-17A, TNF- $\alpha$, and IFN- $\gamma$ expression together with CD28, CD57, and PD-1 between the two groups (Fig. 5C).

We next investigated the expression of CD27, CD28, and CD57 together with cytotoxic molecules in $\mathrm{CD}^{+} \mathrm{T}, \mathrm{CD}^{+} \mathrm{T}, \mathrm{NK}, \mathrm{NKT}$, and $\gamma \delta$ T cells (Fig. 5B). According to the representative scatterplot, GZMB and perforin expression was higher among $\mathrm{CD}^{+} \mathrm{CD}^{+} 7^{+} \mathrm{T}$ cells than $\mathrm{CD}^{+}{ }^{+} \mathrm{CD}_{57}{ }^{-} \mathrm{T}$ cells in both groups; furthermore, $\mathrm{CD} 4^{+} \mathrm{CD}_{57}{ }^{+} \mathrm{GZMB}^{+} \mathrm{T}$ cells and $\mathrm{CD}^{+}{ }^{+} \mathrm{CD} 57^{+}$perforin-positive $\mathrm{T}$ cells were mainly enriched among $\mathrm{CD} 27^{-}$cells and CD28- ${ }^{-}$cells (Fig. 5B and Fig. S1I). As observed in CD4 ${ }^{+}$T cells, GZMB and perforin expression in $\mathrm{CD}^{+} \mathrm{T}, \mathrm{NK}, \mathrm{NKT}$, and $\gamma \delta$ T cells was similarly enriched among $\mathrm{CD} 57^{+}$cells, CD28 ${ }^{-}$ cells, and $\mathrm{CD}_{2} 7^{-}$cells (Fig. 5B and Fig. S1I). We summarized the data in a heatmap and exhibited the distributions of GZMB and perforin expressions together with CD27, CD28, and CD57 between the two groups (Fig. 5D).

Comparable immunosuppressive cells between PPSs and NPSs. Immunosuppressive cells served as the main mechanisms for maintaining immune homeostasis. However, there is considerable controversy regarding whether immunosuppressive cells promote or constrain the formation of fibrosis induced by pathogenic T cells (21-24). We next explored the distribution of immunosuppressive cells in recovered patients. After lysis of the erythrocytes, we directly used cell surface markers to stain monocytic mye-

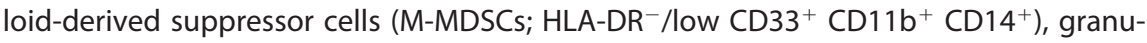
locytic MDSCs (G-MDSCs; HLA-DR ${ }^{-} /$low $\mathrm{CD}_{3}{ }^{+} \mathrm{CD} 11 \mathrm{~b}^{+} \mathrm{CD} 14^{-} \mathrm{CD} 15^{+}$), regulatory $\mathrm{T}$ cells (Tregs; $\mathrm{CD} 4^{+} \mathrm{CD} 127^{-}$/low $\mathrm{CD} 25^{+}$), and regulatory B cells (Bregs; CD19+ ${ }^{+} \mathrm{CD} 24^{+}$ $\left.\mathrm{CD}^{+} 8^{+}\right)(25,26)$. Certainly, it is not stringent to define G-MDSCs by using this method. Patients with acute COVID-19 produce emergency myelopoiesis-generating immunosuppressive myeloid cells (27). But M-MDSC and G-MDSC frequencies did not differ between PPSs and NPSs (Fig. 6A and B). A decrease in HLA-DR on monocytes in acute COVID-19 is associated with severe respiratory failure (28). We did not observe any significant difference in HLA-DR expression on monocyte between the two groups 1 year after discharge (data not shown). Additionally, Tregs and Bregs showed no significant differences among the groups (Fig. 6C and D). Together, our data indicate that immunosuppressive cells may be insufficient to constrain the robust activation of a variety of immune cells in PPSs.

The interrelationship of immune cells and its association with clinical features in COVID-19. Having established that senescent signatures coexist within cytotoxic molecule-secreting cells, we further investigated the interrelationship of immune cells in convalescent patients with COVID-19 (Fig. 7A). Correlation analysis verified that T cells secreting cytotoxic molecules correlated negatively with $\mathrm{CD} 27^{+} \mathrm{CD} 62 \mathrm{~L}^{+} \mathrm{T}$ cells and $\mathrm{CD} 28^{+} \mathrm{T}$ cells but positively with short-lived effector-like CD27- $\mathrm{CD}^{-} \mathrm{L}^{-} \mathrm{T}$ cells, CD57 ${ }^{+} \mathrm{T}$ cells, and KLRG1 ${ }^{+}$T cells (Fig. 7A). CD57 and KLRG-1 are thought to be associated with T cell senescence and also serve as a marker of cytotoxic function (29). Importantly, IL-2 expression within $\mathrm{CD}^{+}{ }^{+} \mathrm{T}$ cells correlated negatively with $\mathrm{CD}^{+} \mathrm{CD}^{-} 7^{-} \mathrm{CD}^{-} \mathrm{L}^{-} \mathrm{T}$ cells, $\mathrm{CD}^{+} \mathrm{CD} 57^{+}$ T cells, CD8 ${ }^{+}$Perforin ${ }^{+} \mathrm{T}$ cells, and $\mathrm{CD}^{+} \mathrm{GZBM}^{+} \mathrm{T}$ cells (Fig. 7A). The downregulated IL-2 expression in $\mathrm{CD}^{+} \mathrm{T}$ cells from PPSs further verifies that these patients retained large amounts of short-lived like CD8 ${ }^{+} \mathrm{T}$ cells that abundantly secrete cytotoxic molecules. Moreover, the expression of perforin and GZMB within NK cells was also positively associated with effector molecule CD57 but inversely with PD-1, NKP30, and NKP46 expression (Fig. 7A). Additionally, GZMB and perforin expression exhibited intrinsic positive correlations among $\mathrm{CD}^{+} \mathrm{T}, \mathrm{CD} 8^{+} \mathrm{T}$, NK, NKT, and $\gamma \delta$ T cells, suggesting that SARS-CoV-2 infection may simultaneously trigger robust activation of a variety of immune cells. More detailed information is displayed in the correlation heatmap depicted in Fig. 7A.

We next sought to determine whether the phenotypic and functional features of immune cells correlate with age and disease type in COVID-19. Correlation analysis suggested that age significantly influenced the phenotypic and functional features of immune cells (Fig. 7B). Senescent and short-lived, such as $\mathrm{CD} 8^{+} \mathrm{T}$ cells, $\mathrm{CD} 8^{+} \mathrm{T}$ cells secreting perforin/granzyme B/IFN- $\gamma$, NK cells secreting perforin/granzyme B, NKP30 ${ }^{+} \mathrm{NKT}, \mathrm{TIM}-3^{+} \mathrm{NKT}$, $\mathrm{NKP}_{3} 0^{+} \gamma \delta \mathrm{T}, \mathrm{KLRG}^{+} \gamma \delta \mathrm{T}$, and $\mathrm{CD} 57^{+} \gamma \delta \mathrm{T}$ cell percentages correlated positively with age, whereas B cells, $\mathrm{CD}^{+} \mathrm{T}$ cells, NKT cells, $\mathrm{CD}^{+} \mathrm{CD}^{+} 7^{+} \mathrm{CD}^{+} 2 \mathrm{~L}^{+} \mathrm{T}$ cells, $\mathrm{NKB1}^{+} \gamma \delta \mathrm{T}$ 
A

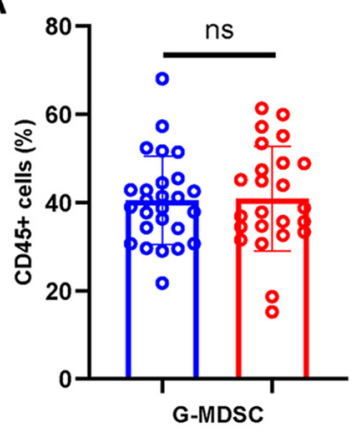

C

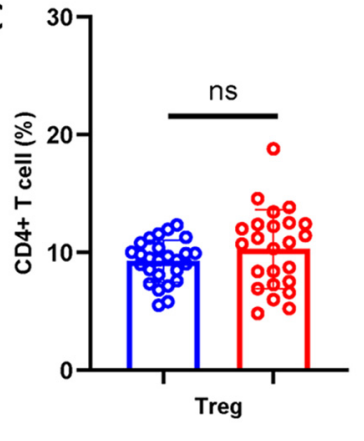

B

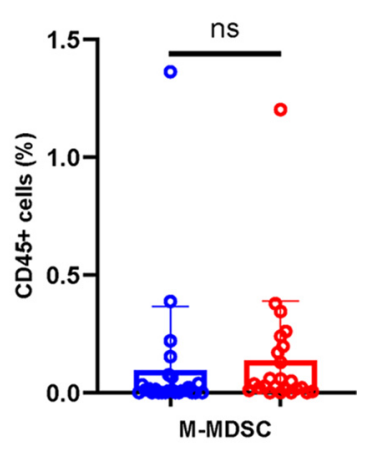

D

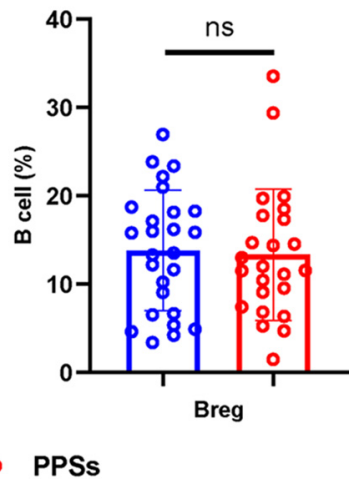

FIG 6 Distribution of immunosuppressive cells between patients with PS and patients without PS. Circulating G-MDSCs, M-MDSCs, Tregs, and Bregs from COVID-19 patients with pulmonary sequelae (PPSs; $n=24$ ) and patients without pulmonary sequelae (NPSs; $n=26$ ) were analyzed by multiparameter flow cytometry. (A) Relative proportions of G-MDSCs between the two groups. (B) Relative proportions of M-MDSCs between the two groups. (C) Relative proportions of Tregs frequencies between the two groups. (D) Relative proportions of Bregs between the two groups. Data are mean $\pm S D$. The Mann-Whitney $U$ test or unpaired two-tailed Student's $t$ tests were used to compare the two groups. ${ }^{*}, P<0.05 ;{ }^{* *}, P<0.01 ;{ }^{* * *}, P<0.001 ;{ }^{* * *}, P<0.0001$.

cells, NKG2D ${ }^{+} \gamma \delta$ T cells, CD27 ${ }^{+}$NK cells, NKG2D ${ }^{+}$NK cells, and NKG2D ${ }^{+}$NKT cell frequencies correlated negatively with age (Fig. 7B). Furthermore, correlation analysis of immunological parameters in PPSs and NPSs revealed that senescent, exhausted GZMB- and perforin-secreting immune cells correlated positively with PS (Fig. 7B). Additionally, CD8 ${ }^{+}$ $\mathrm{CD}_{27}^{-} \mathrm{CD}^{-} \mathrm{L}^{-}$T cell, NK cells, M-MDSCs, NKP30 ${ }^{+} \gamma \delta$ T cell, NKP30 ${ }^{+} \mathrm{NKT}$ cell, $\mathrm{CD}^{+}{ }^{+} \mathrm{IFN}-$ $\gamma^{+}$, and $\mathrm{CD}^{+} \mathrm{IFN}-\gamma^{+} \mathrm{T}$ cell percentages correlated positively with PS (Fig. 7B).

Next, we examined the possibility of using the above-mentioned parameters as prognostic factors for identifying determinants for residual lesions in COVID-19 patients. Multivariate logistic regression analyses identified $\mathrm{CD}^{+} \mathrm{CD}^{+} 7^{+} \mathrm{CD} 2 \mathrm{~L}^{+} \mathrm{T}$ cells (odds ratio [OR], $0.738 ; 95 \%$ confidence interval $[\mathrm{Cl}], 0.590$ to $0.924 ; P=0.008$ ), CD57 ${ }^{+}$NK cells (OR, 1.181; $95 \% \mathrm{Cl}, 1.038$ to $\left.1.343 ; P=0.012\right)$, and CD4 ${ }^{+}$perforin-positive T cells (OR, 1.153; $95 \% \mathrm{Cl}, 0.953$ to $1.396 ; P=0.143$ ) as independent predictors for residual lung lesions (Table 2). Additionally, receiver operating characteristic (ROC) curve was carried out to assess the capacity of the three cell populations to differentiate disease type (PPSs and NPSs). The cutoff values (sensitivity and specificity) are as follows: $\mathrm{CD}^{+} \mathrm{CD}^{+} 7^{+} \mathrm{CD} 2 \mathrm{~L}^{+} \mathrm{T}$ cells, $26.045 \%$ (0.885\% and $\left.0.708 \%\right)$; $\mathrm{CD} 57^{+} \mathrm{NK}$ cells, 74.095\% (0.708\% and $0.885 \%)$; and $\mathrm{CD}^{+}{ }^{+}$Perforin ${ }^{+} \mathrm{T}$ cells, $3.245 \%(0.875 \%$ and $0.423 \%)$. The area under the concentration-time curve (AUC) value of the combination of the three cells $\left(\mathrm{CD} 57^{+} \mathrm{NK}\right.$ cells, CD4 ${ }^{+}$Perforin ${ }^{+} \mathrm{T}$ cells, and $\mathrm{CD} 8^{+} \mathrm{CD}^{+} 7^{+} \mathrm{CD} 2 \mathrm{~L}^{+}$ T cells) was highest (0.942) (Fig. 7C to F).

\section{DISCUSSION}

Although a tremendous global effort by the scientific community has greatly improved our understanding of COVID-19, the immunopathogenesis of PS remains to 
A

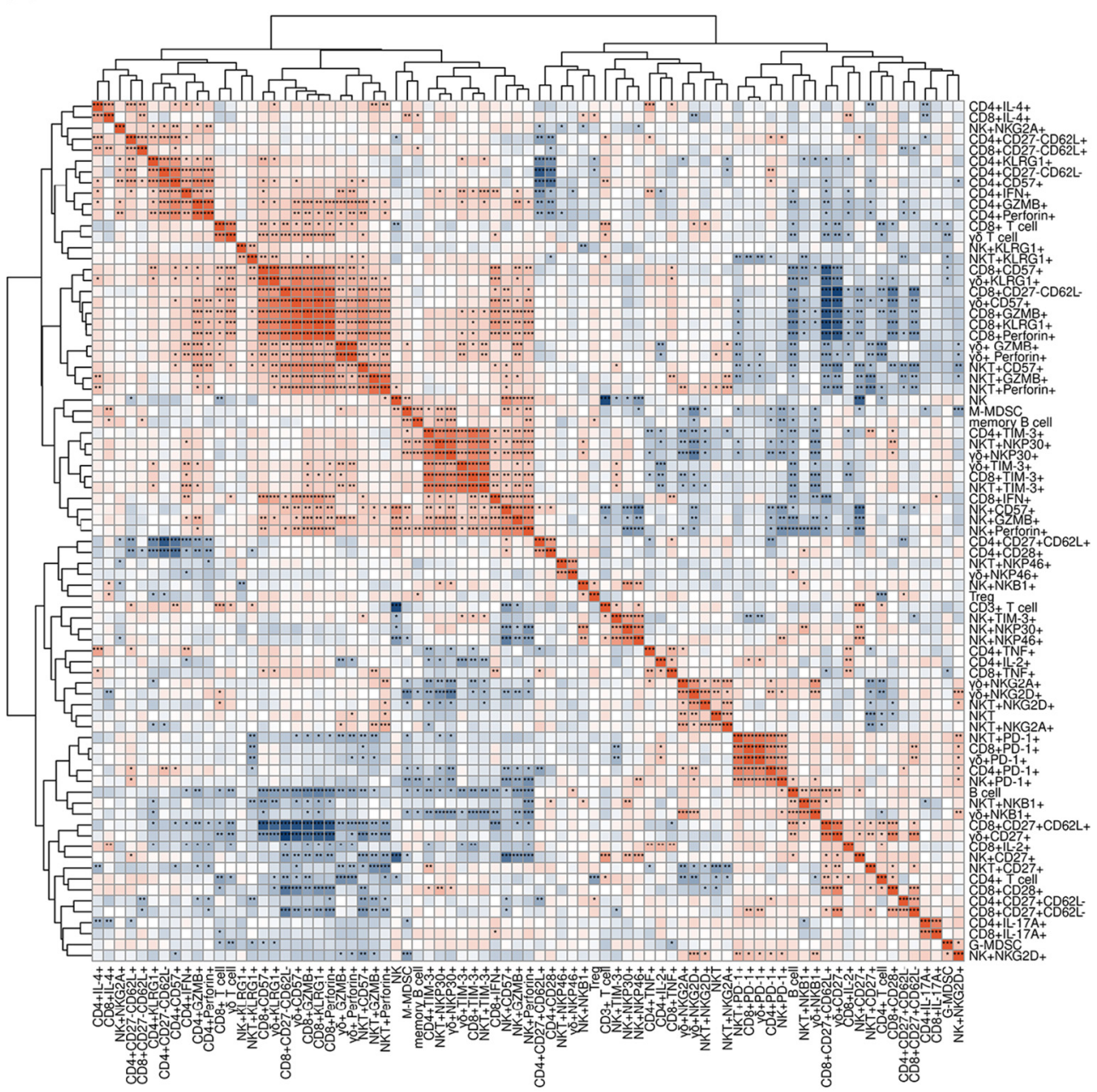

Correlation Heatmap

B
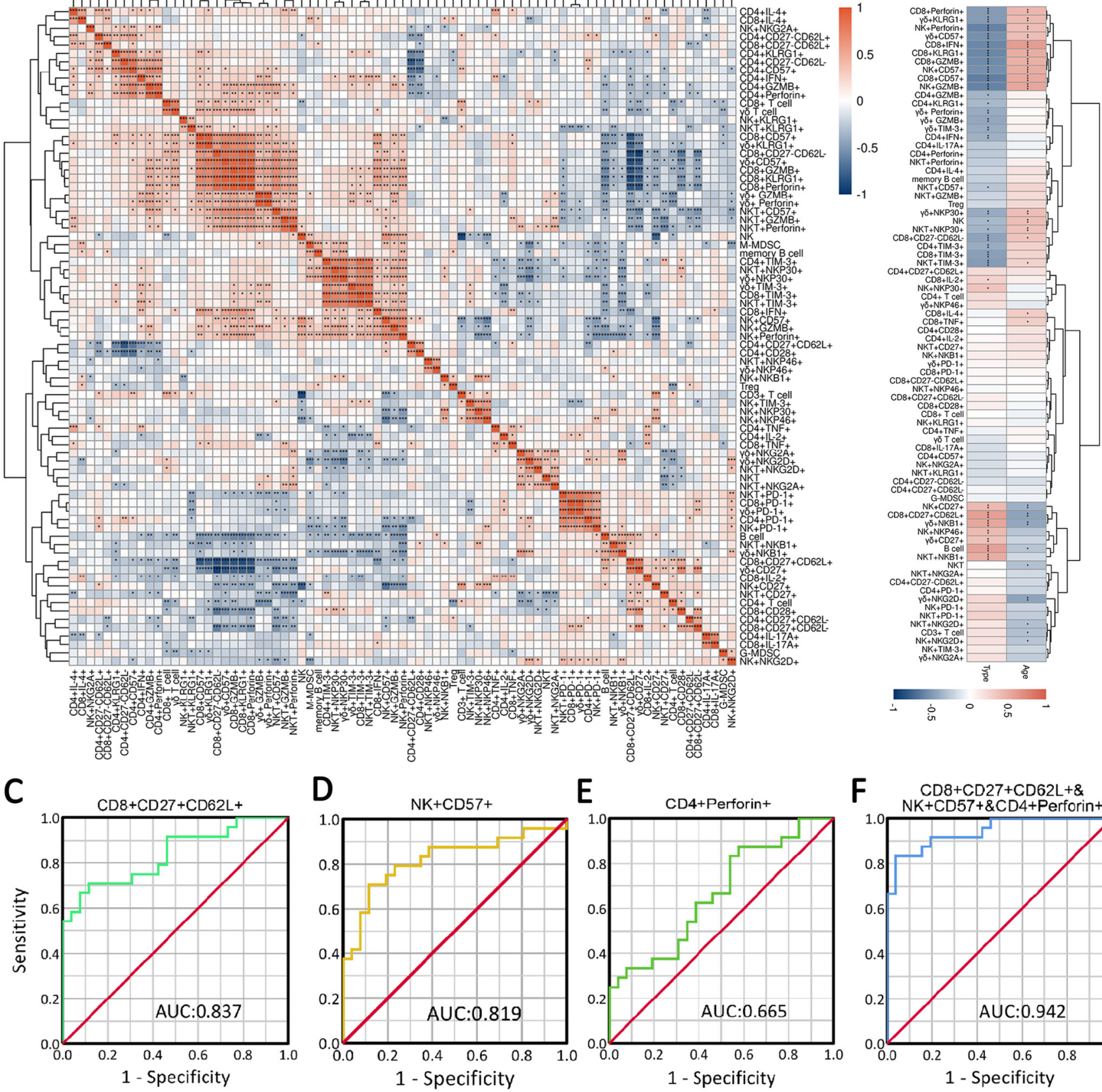

FIG 7 Interrelationship of immune cells and its correlation with clinical features. (A) Correlation heatmap exhibiting the interrelationship of immune cells in all recruited patients with COVID-19. (B) Correlation heatmap exhibiting the correlation of immunological parameters with age and disease type (two types, patients with pulmonary sequelae and patients without pulmonary sequelae). Spearman's rank coefficient was used to determine correlations between two variables. The three most contributing variables $\left(\mathrm{CD} 8^{+} \mathrm{CD} 27^{+} \mathrm{CD} 62^{+} \mathrm{T}\right.$ cells, $\mathrm{CD} 57^{+} \mathrm{NK}$ cells, and $\mathrm{CD} 4^{+}$Perforin ${ }^{+} \mathrm{T}$ cells) were identified by multivariate logistic regression analyses. (C to F) ROC curves were calculated for these selected parameters by using SPSS.

be elucidated. Here, we describe the circulating immune landscape of COVID-19 patients with PS compared with those without PS. Residual lesions in PPSs were mainly GGO and fiber streak shadow. Our study demonstrates that there existed significantly divergent immunological characteristics between PPSs and NPSs 1 year after discharge. Immunological signatures in PPSs were predominated by the accumulation of $\mathrm{CD} 4^{+} \mathrm{T}$ cells secreting IL-17A and short-lived effector-like $\mathrm{CD} 8^{+} \mathrm{T}$ cells with excessive secretion 
TABLE 2 Univariate and multivariate logistic regression analyses of PS

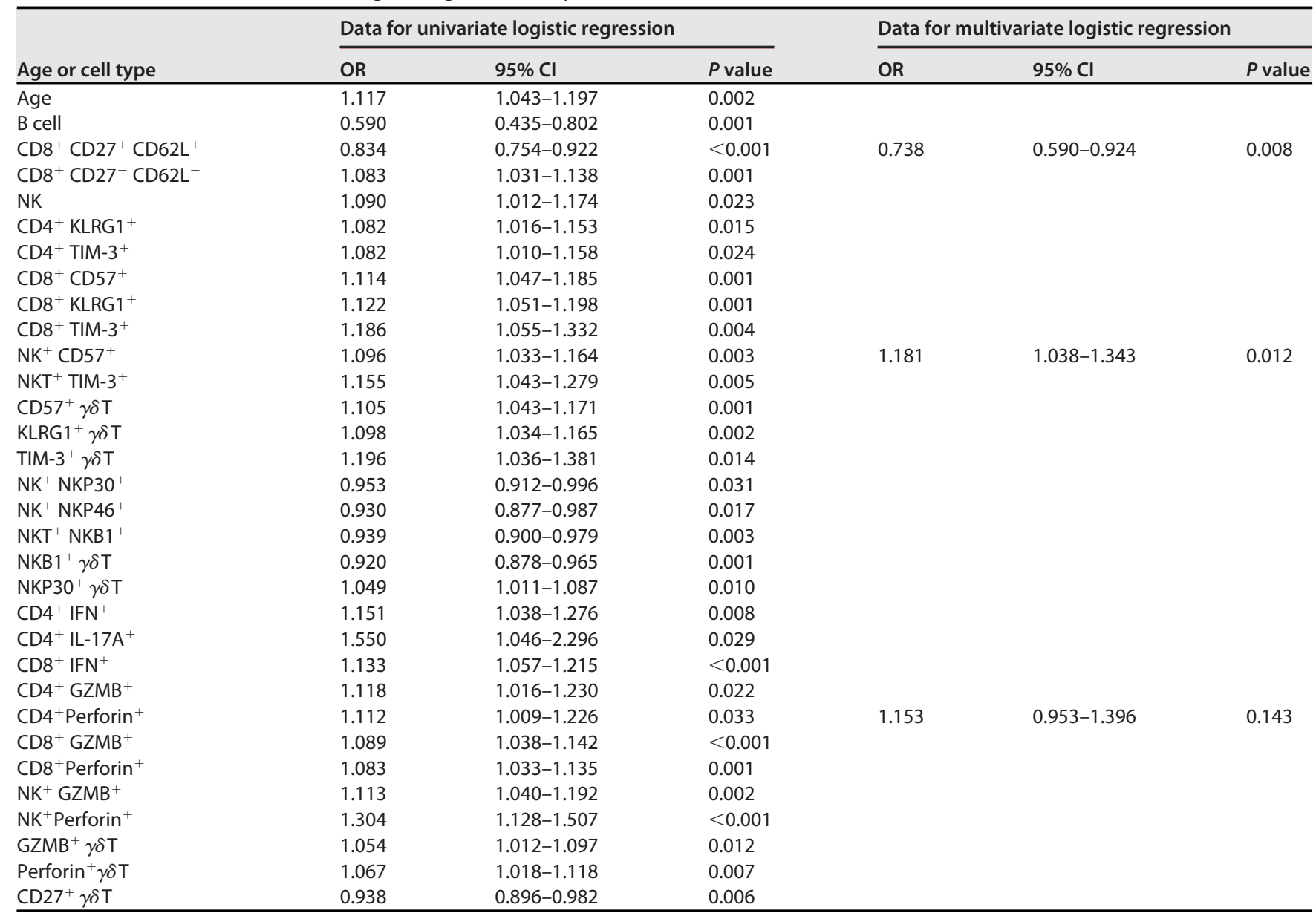

of IFN- $\gamma /$ granzyme B/perforin. NK cells were characterized by excessive secretion of granzyme B and perforin and downregulation of NKP30 and NKP46; NKT and $\gamma \delta$ T cells demonstrated highly activated and exhausted states in PPSs. Overall, we observed robust activation of a variety of immune cells in response to SARS-CoV-2 infection and specific features unique to COVID-19 with PS and hyperinflammation, providing a base for understanding the role of cellular immunity in patients with COVID-19.

Over $80 \%$ of patients with COVID-19 experience lymphopenia and exhibit drastically reduced numbers of various lymphocyte subsets, including CD4 ${ }^{+} \mathrm{T}, \mathrm{CD} 8^{+} \mathrm{T}, \mathrm{B}, \gamma \delta$ $\mathrm{T}$, and NK cells, especially in the peripheral blood of those with severe COVID-19 during the acute phase $(16,30-34)$. Early-stage lymphopenia is thought to correlate with lymphocyte chemotaxis in COVID-19 $(35,36)$. To our surprise, lymphocyte counts were higher in PPSs than in NPSs 1 year after discharge, suggesting that lymphocytes may exit inflamed tissues and undergo clonal expansion after the resolution of SARS-CoV-2 infection. In general, clonal expansion of both innate and adaptive lymphocytes is a critical process for host defense via amplification of lymphocytes specific to the invading pathogen. The NK cell percentage was significantly higher in PPSs than in NPSs, whereas the B cell frequency was lower in the former, suggesting that NK cells underwent more significant clonal expansion. A previous study found that decreased $B$ cells were associated with prolonged viral RNA shedding from the respiratory tract in COVID-19 (37). Nevertheless, the reason for the obvious expansion of NK cells following SARS-CoV-2 clearance in PPSs remains to be elucidated. Prolonged viral RNA shedding may induce clonal expansion of NK cells in an antigen-specific manner, similar to the response to cytomegalovirus infection of acquiring memory features (38). Since 
reverse-transcribed SARS-CoV-2 RNA can integrate into the genome of cultured human cells and can be expressed in patient-derived tissues (39), there might also be latent SARSCoV-2 virus in the reservoir cells in PPSs that could lead to the prolonged expansion of NK cells.

Excessive activation of proinflammatory immune cells can lead to enhanced inflammation and injury during pulmonary viral infection (40). COVID-19 promotes cell polarization of naive and memory cells to effector, cytotoxic, exhausted, and regulatory cells, along with increased late NK cells, and induces gene expression related to inflammation and cellular senescence (41). By examining the phenotypic characteristics of $\mathrm{T}$ cells, we observed a low percentage of $\mathrm{CD} 8{ }^{+} \mathrm{CD} 27^{+} \mathrm{CD} 2 \mathrm{~L}^{+} \mathrm{T}$ cells but a high level of $\mathrm{CD}^{+} \mathrm{CD}^{-} 7^{-} \mathrm{CD}^{-} \mathrm{L}^{-} \mathrm{T}$ cells in PSSs. T cells in PSSs displayed an overall exhausted and senescent phenotype, with overexpression of CD57, KLRG-1, and TIM-3. Functional analysis further revealed that upregulation of degranulation capacity and cytotoxic molecules in $\mathrm{CD}^{+}$and $\mathrm{CD} 8^{+} \mathrm{T}$ cells in PPSs compared with NPSs. Our findings are in line with published papers (42-44). SARS-CoV-2 infection may induce a cytotoxic response, characterized by simultaneous production of GZMB and perforin in T cells, NK cells, and $\gamma \delta$ T cells in PPSs. Excessive activation of cytotoxic T, NK, and $\gamma \delta$ T cells is not protective but, rather, drives pulmonary damage after SARS-CoV-2 infection.

Emerging evidence suggests that COVID-19 survivors have impaired lung function, with the development of pulmonary fibrosis $(2,14)$. Tissue-resident $\mathrm{CD}^{+} \mathrm{T}$ cells drive age-associated chronic lung sequelae after viral pneumonia (45). Also, clonally expanded tissue-resident memory-like Th17 cells may interact with profibrotic macrophages and cytotoxic $\mathrm{CD}^{+} \mathrm{T}$ cells, leading to the formation of pulmonary fibrosis (4). We observed that peripheral blood $\mathrm{CD}^{+}{ }^{+} \mathrm{T}$ cells overexpressed IL-17A/IFN- $\gamma$ and that $\mathrm{CD} 8^{+} \mathrm{T}$ cells overexpressed IFN- $\gamma /$ GZMB/perforin in PSSs. CD103 high Tregs can constrain lung fibrosis induced by $\mathrm{CD} 103^{\text {low }}$ tissue-resident pathogenic $\mathrm{CD} 4^{+} \mathrm{T}$ cells with higher production of effector cytokines, such as IL-4, IL-5, IL-13, IL-17A, and IFN- $\gamma$ (23). However, immunosuppressive cells were comparable between PPSs and NPSs in our study, indicating that these cells may be insufficient to constrain the robust activation of a variety of immune cells in PSSs. Considering that Tregs are equally important to prevent inflammation-induced tissue damage during acute infections and to promote tissue repair, the scholars suggest that Tregs-based strategies could be considered for COVID-19 patient management (46). Hence, immune intervention may be one of the effective treatment measures to reduce the occurrence of PS after the resolution of SARS-CoV-2 infection.

Several other important findings emerged from our data. First, IL-2 $2^{+} \mathrm{T}$ cells, IL-4 ${ }^{+} \mathrm{T}$ cells, and IL-17A ${ }^{+}$T cells hardly expressed CD57 but were enriched among CD28 ${ }^{+}$cells, indicating that autocrine cytokines may provide a tonic signal that inhibits senescence. Furthermore, $\mathrm{CD}^{+}{ }^{+} \mathrm{T}$ cells, $\mathrm{CD} 8^{+} \mathrm{T}$ cells, NK cells, NKT cells, and $\gamma \delta \mathrm{T}$ cells secreting GZMB and perforin were enriched among $\mathrm{CD} 57^{+}$cells, $\mathrm{CD} 28^{-}$cells, and $\mathrm{CD} 27^{-}$cells. Although peripheral blood $\mathrm{CD} 57^{+} \mathrm{T}$ cells exhibit phenotypic and functional features of terminally differentiated effector cells, these cells display enhanced cytotoxic function (47-49). Moreover, GZMB and perforin expression exhibited intrinsic positive correlations among $\mathrm{CD}^{+}{ }^{+} \mathrm{T}$ cells, CD8 ${ }^{+} \mathrm{T}$ cells, NK cells, NKT cells, and $\gamma \delta \mathrm{T}$ cells, suggesting that SARS-CoV-2 infection may simultaneously activate a variety of immune cells. In addition, we also noted downregulated expression of NKP30 and NKP46 in NK cells despite excessive secretion of perforin and GZMB in PPSs. Combined with previous research showing reduced surface expression of NKP30 and NKP46 on adaptive memory NK cells (50), downregulated expression of NKP30 and NKP46 may act as a protective mechanism against tissue damage induced by excessive secretion of perforin and GZMB. Certainly, SARS-CoV-2 may escape the killing of NK cells and damage lung tissue due to downregulated expression of NKP30 and NKP46.

Although our study confirms some findings and provides new data on the innate and adaptive immune landscape of patients with PS who have recovered from COVID191 year after discharge, we recognize limitations that might be overcome with larger sample sizes and matched control populations. Furthermore, there is a lack of 
understanding of the phenotype and function of immune cells from the lungs, which may directly participate in the formation of PS. Hence, the hierarchy of immunodominant circulating blood immune cells may not exactly reflect immunophenotypic features in the lungs. In summary, our study first shows significant differences in immunological characteristics between PPSs and NPSs 1 year after discharge. Although the detailed mechanisms by which cellular immunity participates in the development of PS remain to be investigated, our in-depth analysis of immunological profiling contributes to our understanding of the immunopathogenesis of COVID-19, facilitating the tailoring of more effective and proactive therapies for these patients.

\section{MATERIALS AND METHODS}

Study design and participants. In order to determine the immunopathogenesis of residual lung lesions in COVID-19 survivors 1 year after discharge, a total of 50 convalescent patients were recruited at union hospitals. At the visit, routine blood test, chest computed tomography (CT) scans, and nucleic acid test and antibody detection for SARS-CoV-2 were performed for each participant. The patients were classified as 24 PPSs and 26 NPSs according to radiological characteristics. Patients who reached complete radiological resolution were regarded as NPSs. Complete radiological resolution was defined as the absence of any chest radiographic abnormality potentially related to infection (51). PS, including residual GGO, fibrous stripe shadow, tractive bronchiectasis, reticulation, and bronchovascular bundle distortion, were evaluated by two radiologists. During our recruitment process, we excluded participants with underlying chronic lung diseases and cancers. This study was conducted in accordance with the Declaration of Helsinki and was approved by the Ethics Committee of Union Hospital, Tongji Medical College, Huazhong University of Science and Technology (no. 2020/0004), and written informed consents were obtained from all participants.

Detection of SARS-CoV-2 mRNA and serum SARS-CoV-2 IgG and IgM. SARS-CoV-2 RNA was detected by reverse transcription-PCR (RT-PCR). Total nucleic acid extraction from nasopharyngeal specimens was performed using the QIAamp RNA viral kit (Qiagen), and two sets of primers were taken for two target genes (i.e., open reading frame $1 \mathrm{ab}[\mathrm{ORF} 1 \mathrm{ab}]$ and nucleocapsid protein [N]). Detection of serum SARS-CoV$2 \mathrm{lgG}$ and IgM antibodies was evaluated by IgM/lgG antibody detection kit (Abbott Laboratories, Inc.).

Multiparametric flow cytometric analysis. Peripheral blood $(200 \mu \mathrm{l})$ from convalescent patients with COVID-19 was added into a tube, and $2 \mathrm{ml}$ of red cell lysis buffer was added and incubated for 10 min. After lysis, the sample was washed twice with phosphate-buffered saline (PBS) containing $1 \%$ fetal bovine serum (FBS). Immune cells were surface stained with fluorochrome-conjugated antibodies. The samples were incubated with antibodies for $15 \mathrm{~min}$ at $4^{\circ} \mathrm{C}$. Cells were resuspended in PBS and washed at $400 \times g$ for $6 \mathrm{~min}$. The specimens were immediately evaluated by flow cytometry.

For cytotoxic molecule detection, we isolated peripheral blood mononuclear cells (PBMCs) from heparinized blood by Ficoll-Hypaque gradient centrifugation (Pharmacia, Uppsala, Sweden). For surface staining, PBMCs were washed twice with PBS containing $1 \%$ FBS and stained with fluorochrome-conjugated antibodies. Intracellular staining for granzyme B (GZMB) and perforin was performed after cell fixation and permeabilization (eBioscience), and then intracellular proteins were labeled with the corresponding antibodies conjugated with fluorescent molecules according to the manufacturer's instructions.

A list of the antibodies used is provided in Table S1 in the supplemental material, and the gating strategy is presented in Fig. S1. Flow cytometry was performed using a BD LSRFortessa X-20 (BD Biosciences), and data were analyzed with FlowJo v10 software.

Cytokine production assays. PBMCs were cultured in RPMI 1640 supplemented with 10\% FBS, and cytokine production assays were performed after lymphocytes were stimulated with polymethyl acrylate (PMA; $50 \mathrm{ng} / \mathrm{ml})$ and ionomycin $(1 \mu \mathrm{M})$ in the presence of GolgiStop. After $5 \mathrm{~h}$ at $37^{\circ} \mathrm{C}$, the cells were stained with fluorochrome-associated antibodies specific for surface molecules; next, the cells underwent fixation and permeabilization for intracellular staining with antibodies specific for the following intracellular proteins: IL-2, IL-4, IL-17A, IFN- $\gamma$, and TNF- $\alpha$.

Statistical analysis. The Shapiro-Wilk test was used to evaluate the distribution of variance. Continuous variables with normally and nonnormally distributed data were assessed using unpaired two-tailed Student's $t$ tests or Mann-Whitney $U$ test, respectively. Fisher's exact test was applied to examine categorical variables. Spearman's rank coefficient was used to determine correlations between two variables. Multivariate logistic regression analyses were performed to identify the independent predictive factors of residual lesions. The final model was determined using stepwise logistic regression, with significance level for selection set at a $P$ value of 0.05 . The optimum cutoff values were defined based on their maximum Youden index (sensitivity, +1 ; specificity, -1 ). All tests were 2-sided, and significance levels were set to ${ }^{*}, P<0.05 ;{ }^{* *}, P<0.01 ;{ }^{* * *}, P<0.001$; ${ }^{* * * *}, P<0.0001$; and ns, not significant. All statistical data were analyzed using SPSS version 25.0 statistical software (Chicago, IL, USA), GraphPad Prism 8 software (GraphPad Software, La Jolla, CA), or R software version 4.0.2 (Institute for Statistics and Mathematics, Vienna, Austria).

\section{SUPPLEMENTAL MATERIAL}

Supplemental material is available online only.

FIG S1, PDF file, 0.7 MB.

TABLE S1, PDF file, $0.1 \mathrm{MB}$. 


\section{ACKNOWLEDGMENTS}

We thank all participating patients for their support and cooperation as well as our

colleagues from Imaging Department of Union Hospital.

This work was supported by funds from the Key Special Project of Ministry of Science and Technology, China (no. 2020YFC0845700), Scientific Research Projects of Chinese Academy of Engineering (no. 2020-KYGG-01-07), and Fundamental Research Funds for the Central Universities (no. 2020kfyXGYJ029).

\section{REFERENCES}

1. Wu Z, McGoogan JM. 2020. Characteristics of and important lessons from the coronavirus disease 2019 (COVID-19) outbreak in China: summary of a report of 72314 cases from the Chinese Center for Disease Control and Prevention. JAMA 323:1239-1242. https://doi.org/10.1001/jama.2020.2648.

2. Xu J, Zhou M, Luo P, Yin Z, Wang S, Liao T, Yang F, Wang Z, Yang D, Peng Y, Geng W, Li Y, Zhang H, Yang J. 2021. Plasma metabolomic profiling of patients recovered from COVID-19 with pulmonary sequelae 3 months after discharge. Clin Infect Dis https://doi.org/10.1093/cid/ciab147.

3. Azkur AK, Akdis M, Azkur D, Sokolowska M, van de Veen W, Bruggen MC, O'Mahony L, Gao Y, Nadeau K, Akdis CA. 2020. Immune response to SARSCoV-2 and mechanisms of immunopathological changes in COVID-19. Allergy 75:1564-1581. https://doi.org/10.1111/all.14364.

4. Zhao $Y$, Kilian C, Turner J-E, Bosurgi L, Roedl K, Bartsch P, Gnirck A-C, Cortesi F, Schultheiß C, Hellmig M, Enk LUB, Hausmann F, Borchers A, Wong MN, Paust H-J, Siracusa F, Scheibel N, Herrmann M, Rosati E, Bacher $P$, Kylies D, Jarczak D, Lütgehetmann M, Pfefferle S, Steurer S, Zur-Wiesch JS, Puelles VG, Sperhake J-P, Addo MM, Lohse AW, Binder M, Huber S, Huber TB, Kluge S, Bonn S, Panzer U, Gagliani N, Krebs CF. 2021. Clonal expansion and activation of tissue-resident memory-like Th17 cells expressing GM-CSF in the lungs of patients with severe COVID-19. Sci Immunol 6:eabf6692. https://doi.org/10.1126/sciimmunol.abf6692.

5. Rodda LB, Netland J, Shehata L, Pruner KB, Morawski PA, Thouvenel CD, Takehara KK, Eggenberger J, Hemann EA, Waterman HR, Fahning ML, Chen Y, Hale M, Rathe J, Stokes C, Wrenn S, Fiala B, Carter L, Hamerman JA, King NP, Gale M, Jr., Campbell DJ, Rawlings DJ, Pepper M. 2021. Functional SARS-CoV-2-specific immune memory persists after mild COVID-19. Cell 184:169-183. https://doi.org/10.1016/j.cell.2020.11.029.

6. Jiang XL, Wang GL, Zhao XN, Yan FH, Yao L, Kou ZQ, Ji SX, Zhang XL, Li CB, Duan $\sqcup$, Li Y, Zhang YW, Duan Q, Wang TC, Li ET, Wei X, Wang QY, Wang XF, Sun WY, Gao YW, Kang DM, Zhang JY, Ma MJ. 2021. Lasting antibody and T cell responses to SARS-CoV-2 in COVID-19 patients three months after infection. Nat Commun 12:897. https://doi.org/10.1038/s41467-021-21155-x.

7. Sekine T, Perez-Potti A, Rivera-Ballesteros O, Stralin K, Gorin JB, Olsson A, Llewellyn-Lacey S, Kamal H, Bogdanovic G, Muschiol S, Wullimann DJ, Kammann T, Emgard J, Parrot T, Folkesson E, Karolinska C-SG, Rooyackers O, Eriksson LI, Henter Jl, Sonnerborg A, Allander T, Albert J, Nielsen M, Klingstrom J, Gredmark-Russ S, Bjorkstrom NK, Sandberg JK, Price DA, Ljunggren HG, Aleman S, Buggert M, Karolinska COVID-19 Study Group. 2020. Robust T cell immunity in convalescent individuals with asymptomatic or mild COVID-19. Cell 183:158-168. https://doi.org/10.1016/j.cell.2020 .08 .017 .

8. Grifoni A, Weiskopf D, Ramirez SI, Mateus J, Dan JM, Moderbacher CR, Rawlings SA, Sutherland A, Premkumar L, Jadi RS, Marrama D, de Silva AM, Frazier A, Carlin AF, Greenbaum JA, Peters B, Krammer F, Smith DM, Crotty S, Sette A. 2020. Targets of T cell responses to SARS-CoV-2 coronavirus in humans with COVID-19 disease and unexposed individuals. Cell 181:1489-1501. https://doi.org/10.1016/j.cell.2020.05.015.

9. Le Bert N, Tan AT, Kunasegaran K, Tham CYL, Hafezi M, Chia A, Chng MHY, Lin M, Tan N, Linster M, Chia WN, Chen MI, Wang LF, Ooi EE, Kalimuddin S, Tambyah PA, Low JG, Tan YJ, Bertoletti A. 2020. SARS-CoV-2-specific T cell immunity in cases of COVID-19 and SARS, and uninfected controls. Nature 584:457-462. https://doi.org/10.1038/s41586-020-2550-Z.

10. Ni L, Ye F, Cheng ML, Feng Y, Deng YQ, Zhao H, Wei P, Ge J, Gou M, Li X, Sun L, Cao T, Wang P, Zhou C, Zhang R, Liang P, Guo H, Wang X, Qin CF, Chen F, Dong C. 2020. Detection of SARS-CoV-2-specific humoral and cellular immunity in COVID-19 convalescent individuals. Immunity 52: 971-977. https://doi.org/10.1016/j.immuni.2020.04.023.

11. Peng Y, Mentzer AJ, Liu G, Yao X, Yin Z, Dong D, Dejnirattisai W, Rostron T, Supasa P, Liu C, Lopez-Camacho C, Slon-Campos J, Zhao Y, Stuart DI, Paesen GC, Grimes JM, Antson AA, Bayfield OW, Hawkins D, Ker DS, Wang
B, Turtle L, Subramaniam K, Thomson P, Zhang P, Dold C, Ratcliff J, Simmonds P, de Silva T, Sopp P, Wellington D, Rajapaksa U, Chen YL, Salio M, Napolitani G, Paes W, Borrow P, Kessler BM, Fry JW, Schwabe NF, Semple MG, Baillie JK, Moore SC, Openshaw PJM, Ansari MA, Dunachie S, Barnes E, Frater J, Kerr G, Goulder P, Lockett T, et al. 2020. Broad and strong memory CD4(+) and CD8(+) T cells induced by SARS-CoV-2 in UK convalescent individuals following COVID-19. Nat Immunol 21: 1336-1345. https://doi.org/10.1038/s41590-020-0782-6.

12. Herold S, Becker C, Ridge KM, Budinger GR. 2015. Influenza virus-induced lung injury: pathogenesis and implications for treatment. Eur Respir J 45: 1463-1478. https://doi.org/10.1183/09031936.00186214.

13. Melms JC, Biermann J, Huang H, Wang Y, Nair A, Tagore S, Katsyv I, Rendeiro AF, Amin AD, Schapiro D, Frangieh CJ, Luoma AM, Filliol A, Fang Y, Ravichandran $H$, Clausi MG, Alba GA, Rogava M, Chen SW, Ho P, Montoro DT, Kornberg AE, Han AS, Bakhoum MF, Anandasabapathy N, Suarez-Farinas M, Bakhoum SF, Bram Y, Borczuk A, Guo XV, Lefkowitch JH, Marboe C, Lagana SM, Del Portillo A, Zorn E, Markowitz GS, Schwabe RF, Schwartz RE, Elemento O, Saqi A, Hibshoosh H, Que J, Izar B. 2021. A molecular single-cell lung atlas of lethal COVID-19. Nature 595:114-119. https://doi.org/10.1038/s41586-021-03569-1.

14. Han X, Fan Y, Alwalid O, Li N, Jia X, Yuan M, Li Y, Cao Y, Gu J, Wu H, Shi H. 2021. Six-month follow-up chest CT findings after severe COVID-19 pneumonia. Radiology 299:E177-E186. https://doi.org/10.1148/radiol.2021203153.

15. Liu D, Zhang W, Pan F, Li L, Yang L, Zheng D, Wang J, Liang B. 2020. The pulmonary sequalae in discharged patients with COVID-19: a short-term observational study. Respir Res 21:125. https://doi.org/10.1186/s12931 -020-01385-1.

16. Guan WJ, Ni ZY, Hu Y, Liang WH, Ou CQ, He JX, Liu L, Shan H, Lei CL, Hui DSC, Du B, Li LJ, Zeng G, Yuen KY, Chen RC, Tang CL, Wang T, Chen PY, Xiang J, Li SY, Wang JL, Liang ZJ, Peng YX, Wei L, Liu Y, Hu YH, Peng P, Wang JM, Liu JY, Chen Z, Li G, Zheng ZJ, Qiu SQ, Luo J, Ye CJ, Zhu SY, Zhong NS, China Medical Treatment Expert Group for Covid-19. 2020. Clinical characteristics of coronavirus disease 2019 in China. N Engl J Med 382:1708-1720. https://doi.org/10.1056/NEJMoa2002032.

17. Pandit A, De Boer RJ. 2019. Stochastic inheritance of division and death times determines the size and phenotype of $\mathrm{CD} 8(+) \mathrm{T}$ cell families. Front Immunol 10:436. https://doi.org/10.3389/fimmu.2019.00436.

18. Hammer $Q$, Ruckert T, Romagnani C. 2018. Natural killer cell specificity for viral infections. Nat Immunol 19:800-808. https://doi.org/10.1038/s41590 -018-0163-6.

19. Godfrey DI, Stankovic S, Baxter AG. 2010. Raising the NKT cell family. Nat Immunol 11:197-206. https://doi.org/10.1038/ni.1841.

20. Yazdanifar M, Mashkour N, Bertaina A. 2020. Making a case for using gammadelta T cells against SARS-CoV-2. Crit Rev Microbiol 46:689-702. https://doi.org/10.1080/1040841X.2020.1822279.

21. Fernandez IE, Greiffo FR, Frankenberger M, Bandres J, Heinzelmann K, Neurohr C, Hatz R, Hartl D, Behr J, Eickelberg O. 2016. Peripheral blood myeloid-derived suppressor cells reflect disease status in idiopathic pulmonary fibrosis. Eur Respir J 48:1171-1183. https://doi.org/10.1183/ 13993003.01826-2015.

22. Lebrun A, Lo Re S, Chantry M, Izquierdo Carerra $X$, Uwambayinema $F$, Ricci D, Devosse R, Ibouraadaten S, Brombin L, Palmai-Pallag M, Yakoub Y, Pasparakis M, Lison D, Huaux F. 2017. CCR2(+) monocytic myeloidderived suppressor cells (M-MDSCs) inhibit collagen degradation and promote lung fibrosis by producing transforming growth factor-beta1. J Pathol 243:320-330. https://doi.org/10.1002/path.4956.

23. Ichikawa T, Hirahara K, Kokubo K, Kiuchi M, Aoki A, Morimoto Y, Kumagai J, Onodera A, Mato N, Tumes DJ, Goto Y, Hagiwara K, Inagaki Y, Sparwasser T, Tobe K, Nakayama T. 2019. CD103(hi) Treg cells constrain 
lung fibrosis induced by CD103(lo) tissue-resident pathogenic CD4 T cells Nat Immunol 20:1469-1480. https://doi.org/10.1038/s41590-019-0494-y.

24. Zhang M, Zhang S. 2020. T cells in fibrosis and fibrotic diseases. Front Immunol 11:1142. https://doi.org/10.3389/fimmu.2020.01142.

25. Cassetta L, Baekkevold ES, Brandau S, Bujko A, Cassatella MA, Dorhoi A, Krieg C, Lin A, Lore K, Marini O, Pollard JW, Roussel M, Scapini P, Umansky V, Adema GJ. 2019. Deciphering myeloid-derived suppressor cells: isolation and markers in humans, mice and non-human primates. Cancer Immunol Immunother 68:687-697. https://doi.org/10.1007/s00262-019 -02302-2.

26. Krejcik J, Casneuf T, Nijhof IS, Verbist B, Bald J, Plesner T, Syed K, Liu K, van de Donk NW, Weiss BM, Ahmadi T, Lokhorst HM, Mutis T, Sasser AK. 2016. Daratumumab depletes CD38+ immune regulatory cells, promotes T-cell expansion, and skews T-cell repertoire in multiple myeloma. Blood 128: 384-394. https://doi.org/10.1182/blood-2015-12-687749.

27. Silvin A, Chapuis N, Dunsmore G, Goubet AG, Dubuisson A, Derosa L, Almire C, Henon C, Kosmider O, Droin N, Rameau P, Catelain C, Alfaro A, Dussiau C, Friedrich C, Sourdeau E, Marin N, Szwebel TA, Cantin D, Mouthon L, Borderie D, Deloger M, Bredel D, Mouraud S, Drubay D, Andrieu M, Lhonneur AS, Saada V, Stoclin A, Willekens C, Pommeret F, Griscelli F, Ng LG, Zhang Z, Bost P, Amit I, Barlesi F, Marabelle A, Pene F, Gachot B, Andre F, Zitvogel L, Ginhoux F, Fontenay M, Solary E. 2020. Elevated calprotectin and abnormal myeloid cell subsets discriminate severe from mild COVID-19. Cell 182:1401-1418. https://doi.org/10.1016/j.cell .2020.08.002.

28. Ong EZ, Chan YFZ, Leong WY, Lee NMY, Kalimuddin S, Haja Mohideen SM, Chan KS, Tan AT, Bertoletti A, Ooi EE, Low JGH. 2020. A dynamic immune response shapes COVID-19 progression. Cell Host Microbe 27: 879-882.e2. https://doi.org/10.1016/j.chom.2020.03.021.

29. Diggins KE, Serti E, Muir V, Rosasco M, Lu T, Balmas E, Nepom G, Long SA, Linsley PS. 2021. Exhausted-like CD8 + T cell phenotypes linked to C-peptide preservation in alefacept-treated T1D subjects. JCI Insight 6:e142680. https://doi.org/10.1172/jci.insight.142680.

30. Liu J, Li S, Liu J, Liang B, Wang X, Wang H, Li W, Tong Q, Yi J, Zhao L, Xiong L, Guo C, Tian J, Luo J, Yao J, Pang R, Shen H, Peng C, Liu T, Zhang Q, Wu J, Xu L, Lu S, Wang B, Weng Z, Han C, Zhu H, Zhou R, Zhou H, Chen X, Ye P, Zhu B, Wang L, Zhou W, He S, He Y, Jie S, Wei P, Zhang J, Lu Y, Wang W, Zhang L, Li L, Zhou F, Wang J, Dittmer U, Lu M, Hu Y, Yang D, Zheng X. 2020. Longitudinal characteristics of lymphocyte responses and cytokine profiles in the peripheral blood of SARS-CoV-2 infected patients. EBioMedicine 55:102763. https://doi.org/10.1016/j.ebiom.2020.102763.

31. Li S, Jiang L, Li X, Lin F, Wang Y, Li B, Jiang T, An W, Liu S, Liu H, Xu P, Zhao L, Zhang L, Mu J, Wang H, Kang J, Li Y, Huang L, Zhu C, Zhao S, Lu J, Ji J, Zhao J. 2020. Clinical and pathological investigation of patients with severe COVID-19. JCI Insight 5:e138070. https://doi.org/10.1172/jci.insight.138070.

32. Wang F, Hou H, Luo Y, Tang G, Wu S, Huang M, Liu W, Zhu Y, Lin Q, Mao L, Fang M, Zhang H, Sun Z. 2020. The laboratory tests and host immunity of COVID-19 patients with different severity of illness. JCI Insight 5:e137799. https://doi.org/10.1172/jci.insight.137799.

33. Odak I, Barros-Martins J, Bosnjak B, Stahl K, David S, Wiesner O, Busch M, Hoeper MM, Pink I, Welte T, Cornberg M, Stoll M, Goudeva L, Blasczyk R, Ganser A, Prinz I, Forster R, Koenecke C, Schultze-Florey CR. 2020. Reappearance of effector T cells is associated with recovery from COVID-19. EBioMedicine 57:102885. https://doi.org/10.1016/j.ebiom.2020.102885.

34. Zheng M, Gao Y, Wang G, Song G, Liu S, Sun D, Xu Y, Tian Z. 2020. Functional exhaustion of antiviral lymphocytes in COVID-19 patients. Cell Mol Immunol 17:533-535. https://doi.org/10.1038/s41423-020-0402-2.

35. Oja $A E$, Saris A, Ghandour CA, Kragten NAM, Hogema BM, Nossent EJ, Heunks LMA, Cuvalay S, Slot E, Linty F, Swaneveld FH, Vrielink H, Vidarsson G, Rispens T, van der Schoot E, van Lier RAW, Ten Brinke A, Hombrink P. 2020. Divergent SARS-CoV-2-specific T- and B-cell responses in severe but not mild COVID-19 patients. Eur J Immunol 50:1998-2012. https://doi.org/ 10.1002/eji.202048908.

36. Wiersinga WJ, Rhodes A, Cheng AC, Peacock SJ, Prescott HC. 2020. Pathophysiology, transmission, diagnosis, and treatment of coronavirus disease 2019 (COVID-19): a review. JAMA 324:782-793. https://doi.org/10.1001/ jama.2020.12839.

37. Hao S, Lian J, Lu Y, Jia H, Hu J, Yu G, Wang X, Xu K, Ni Q, Li Y, Liu J, Zhao H, Zhang X, Yu L, Yu X, Xiang D, Chen Y, Zheng S, Qiu Y, Li L, Liang T, Yang Y, Sheng J. 2020. Decreased B cells on admission associated with prolonged viral RNA shedding from the respiratory tract in coronavirus disease 2019: a case-control study. J Infect Dis 222:367-371. https://doi.org/10.1093/ infdis/jiaa311.

38. Sun JC, Beilke JN, Lanier LL. 2009. Adaptive immune features of natural killer cells. Nature 457:557-561. https://doi.org/10.1038/nature07665.

39. Zhang L, Richards A, Barrasa MI, Hughes SH, Young RA, Jaenisch R. 2021. Reverse-transcribed SARS-CoV-2 RNA can integrate into the genome of cultured human cells and can be expressed in patient-derived tissues. Proc Natl Acad Sci U S A 118:e2105968118. https://doi.org/10.1073/pnas .2105968118 .

40. Yoo JK, Kim TS, Hufford MM, Braciale TJ. 2013. Viral infection of the lung: host response and sequelae. J Allergy Clin Immunol 132:1263-1276; quiz 1277. https://doi.org/10.1016/j.jaci.2013.06.006.

41. Zheng Y, Liu X, Le W, Xie L, Li H, Wen W, Wang S, Ma S, Huang Z, Ye J, Shi W, Ye Y, Liu Z, Song M, Zhang W, Han JJ, Belmonte JCI, Xiao C, Qu J, Wang H, Liu GH, Su W. 2020. A human circulating immune cell landscape in aging and COVID-19. Protein Cell 11:740-770. https://doi.org/10.1007/ s13238-020-00762-2.

42. Westmeier J, Paniskaki K, Karakose Z, Werner T, Sutter K, Dolff S, Overbeck M, Limmer A, Liu J, Zheng X, Brenner T, Berger MM, Witzke O, Trilling M, Lu M, Yang D, Babel N, Westhoff T, Dittmer U, Zelinskyy G. 2020. Impaired cytotoxic CD8(+) T cell response in elderly COVID-19 patients. mBio 11: e2105968118. https://doi.org/10.1128/mBio.02243-20.

43. Meckiff BJ, Ramirez-Suastegui C, Fajardo V, Chee SJ, Kusnadi A, Simon $H$, Eschweiler S, Grifoni A, Pelosi E, Weiskopf D, Sette A, Ay F, Seumois G, Ottensmeier $\mathrm{CH}$, Vijayanand P. 2020. Imbalance of regulatory and cytotoxic SARS-CoV-2-reactive CD4(+) T cells in COVID-19. Cell 183: 1340-1353. https://doi.org/10.1016/j.cell.2020.10.001.

44. Maucourant C, Filipovic I, Ponzetta A, Aleman S, Cornillet M, Hertwig L, Strunz B, Lentini A, Reinius B, Brownlie D, Cuapio A, Ask EH, Hull RM, Haroun-Izquierdo A, Schaffer M, Klingstrom J, Folkesson E, Buggert M, Sandberg JK, Eriksson LI, Rooyackers O, Ljunggren HG, Malmberg KJ, Michaelsson J, Marquardt N, Hammer Q, Stralin K, Bjorkstrom NK, Karolinska C-SG, Karolinska COVID-19 Study Group. 2020. Natural killer cell immunotypes related to COVID-19 disease severity. Sci Immunol 5. https://doi.org/10.1126/sciimmunol.abd6832.

45. Goplen NP, Wu Y, Son YM, Li C, Wang Z, Cheon IS, Jiang L, Zhu B, Ayasoufi K, Chini EN, Johnson AJ, Vassallo R, Limper AH, Zhang N, Sun J. 2020. Tissue-resident $C D 8(+) \mathrm{T}$ cells drive age-associated chronic lung sequelae after viral pneumonia. Sci Immunol 5:eabc4557. https://doi.org/10.1126/ sciimmunol.abc4557.

46. Stephen-Victor E, Das M, Karnam A, Pitard B, Gautier JF, Bayry J. 2020. Potential of regulatory T-cell-based therapies in the management of severe COVID-19. Eur Respir J 56:2002182. https://doi.org/10.1183/ 13993003.02182-2020.

47. Huang B, Liu R, Wang $P$, Yuan Z, Yang J, Xiong H, Zhang N, Huang Q, Fu X, Sun W, Li L. 2020. CD8(+)CD57(+) T cells exhibit distinct features in human non-small cell lung cancer. J Immunother Cancer 8:e000639. https://doi.org/10.1136/jitc-2020-000639.

48. Chiang SC, Theorell J, Entesarian M, Meeths M, Mastafa M, Al-Herz W, Frisk $P$, Gilmour KC, Ifversen $M$, Langenskiold $C$, Machaczka $M$, Naqvi $A$, Payne J, Perez-Martinez A, Sabel M, Unal E, Unal S, Winiarski J, Nordenskjold M, Ljunggren HG, Henter Jl, Bryceson YT. 2013. Comparison of primary human cytotoxic T-cell and natural killer cell responses reveal similar molecular requirements for lytic granule exocytosis but differences in cytokine production. Blood 121:1345-1356. https://doi.org/10 .1182/blood-2012-07-442558.

49. Chattopadhyay PK, Betts MR, Price DA, Gostick E, Horton $H$, Roederer M, De Rosa SC. 2009. The cytolytic enzymes granyzme A, granzyme B, and perforin: expression patterns, cell distribution, and their relationship to cell maturity and bright CD57 expression. J Leukoc Biol 85:88-97. https:// doi.org/10.1189/jlb.0208107.

50. Barrow AD, Martin CJ, Colonna M. 2019. The natural cytotoxicity receptors in health and disease. Front Immunol 10:909. https://doi.org/10.3389/ fimmu.2019.00909.

51. Bruns AH, Oosterheert JJ, El Moussaoui R, Opmeer BC, Hoepelman Al, Prins JM. 2010. Pneumonia recovery: discrepancies in perspectives of the radiologist, physician and patient. J Gen Intern Med 25:203-206. https:// doi.org/10.1007/s11606-009-1182-7. 